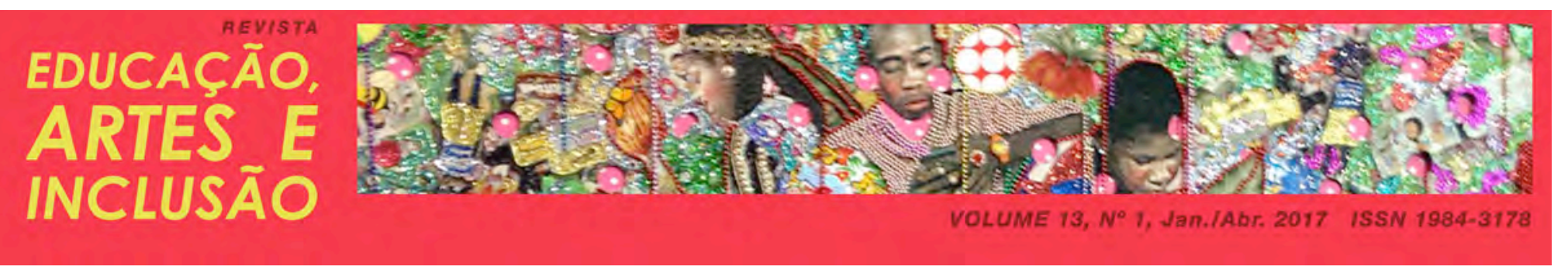

\title{
CIDADE DE VITÓRIA (ES) NOS CARTÕES-POSTAIS: A CIDADE EM EXPOSIÇÃO E SUAS POTENCIALIDADES EDUCATIVAS
}

\section{CITY OF VITÓRIA (ES) IN POSTCARDS: THE CITY ON DISPLAY AND THEIR EDUCATIONAL POTENTIAL}

DOI: http://dx.doi.org/10.5965/1984317813012017167

Priscila de Souza Chisté - IFES

Dilza Côco - IFES

\begin{abstract}
RESUMO
A análise de dados evocados em plataformas virtuais de pesquisa aponta que os estudos sobre a cidade, por meio de cartões-postais, constituem-se como lócus de pesquisa com pouca abrangência na área da educação brasileira. Diante desse nicho de pesquisa, o artigo que segue, tem como objetivo principal apresentar estudo sobre o processo de modernização da cidade de Vitória, no Espírito Santo, por meio dos cartões-postais, com vistas a analisar também o potencial histórico e educativo desse gênero discursivo. A pesquisa insere-se no rol das investigações documentais e de cunho bibliográfico, tendo em vista que investiga documentos como mapas e cartões-postais de Vitória e dialoga com estudos sobre o processo de modernização dessa cidade. Apresenta também depoimentos de integrantes do Grupo de Pesquisa sobre Educação na Cidade e Humanidades, do Instituto Federal do Espírito Santo, de modo a analisar, por meio de tais dados empíricos, se a visita à exposição "Postais do Espírito Santo: acervo Monsenhor Jamil Abib" contribuiu com o entendimento do processo de modernização da capital capixaba. Para discorrer sobre esses depoimentos, estudos e imagens, a pesquisa interage com apontamentos bakhtinianos referentes aos conceitos de dialogismo e polifonia. Nessa perspectiva, concebe os cartões-postais como fonte de preservação de fragmentos da memória da cidade e realça que a análise comparativa desses gêneros discursivos pode evidenciar o movimento de transformação do espaço urbano.
\end{abstract}

Palavras-chave: Cidade. Processo de modernização. Cartões-Postais.

\begin{abstract}
The analysis of data evoked in virtual platforms of research indicates that the studies on the city, through postcards, constitute as a locus of research with little scope in the Brazilian education area. In view of this research niche, the main objective of this article is to present a study about the process of modernization of the city of Vitória, in Espírito Santo, by means of postcards, in order to analyze the historical and educational potential of this genre discursive. The research is part of the documentary research and bibliographical research, considering that it investigates documents such as maps and postcards of Vitória and dialogues with studies on the modernization process of this city. It also presents testimonies of members of the Study and Research Group on Teaching in the City and Humanities of the Instituto Federal do Espírito Santo, in order to analyze, through such empirical data, the visit to the exhibition "Postcards of the Espírito Santo: Collection Monsenhor Jamil Abib" contributed to the understanding of the process of modernization of the capital of Espírito Santo. To discuss these testimonies, studies and images, the research interacts with bakhtinian notes referring to the concepts of dialogism and polyphony. In this perspective, he conceives the postcards as a source of preservation of fragments of the memory of the city and emphasizes that the comparative analysis of these discursive genres can evidence the movement of transformation of the urban space.
\end{abstract}

Keywords: City. Modernization process. Postal cards. 


\section{INTRODUÇÃO}

Ítalo Calvino, no livro "As cidades invisíveis", apresenta conversas do viajante veneziano Marco Polo com o imperador mongol Kublai Khan. Marco Polo conta as histórias das cidades que o Imperador conquistou, entre elas Maurília:

Em Maurília, o viajante é convidado a visitar a cidade e ao mesmo tempo em que observa uns velhos cartões-postais ilustrados que mostram como esta havia sido: a praça idêntica com uma galinha no lugar da estação de ônibus, o coreto no lugar do viaduto, duas meninas com sombrinhas brancas no lugar da fábrica de explosivos. Para não decepcionar os habitantes é necessário que o viajante louve a cidade dos cartões-postais e preferi-la à atual, tomando cuidado, porém, em conter seu pesar em relação às mudanças nos limites das regras bem precisas: reconhecendo que a magnificência e prosperidade de Maurília transformada em metrópole, se comparada com a velha Maurília provinciana, não restituem uma certa graça perdida, a qual, todavia, só agora pode ser apreciada através dos velhos cartões-postais, enquanto antes, em presença da Maurília provinciana não se via absolutamente nada de gracioso, e ver-se-ia ainda menos hoje em dia, se Maurília houvesse permanecido antes, e que, de qualquer modo, a metrópole tem esse atrativo adicional - que mediante o que se tornou pode-se recordar com saudades daquilo que se foi.

Evitem dizer que algumas vezes as cidades diferentes sucedem-se no mesmo solo e com o mesmo nome, nascem e morrem sem se conhecer, incomunicáveis entre si. Às vezes, os nomes dos habitantes permanecem iguais, e o sotaque das vozes, e até mesmo os traçados dos rostos; mas os deuses que vivem com os nomes e nos solos foram embora sem avisar e em seus lugares acomodaram-se deuses estranhos. É inútil querer saber se estes são melhores do que os antigos, dado que não existe nenhuma relação entre eles, da mesma forma que os velhos postais não representam Maurília do passado, mas uma outra cidade que por acaso se chamava Maurília (CALVINO, 1990, p. 31).

Nesse trecho do livro é possível observar o saudosismo dos moradores de Maurília e a valorização que dão as imagens que rememoram a cidade em tempos distantes. Olhar a cidade atual por meio de postais antigos, comparar os espaços, relacionar o rural e o urbano, a tradição e a modernidade ${ }^{1}$, as contradições entre o rural e o industrial são aspectos elencados

\footnotetext{
${ }^{1}$ De acordo com o Dicionário Básico de Filosofia de Japiassú e Marcondes (2008) modernidade refere-se à
} 
pelo narrador. Ele aponta a preferência dos moradores pela cidade antiga, provinciana, revelando o pesar ocasionado pelo progresso de Maurília até se constituir como uma metrópole. Tal saudosismo não ocorreria se Maurília tivesse permanecido nos moldes provincianos, ele só acontece porque a cidade foi transformada em um local diferente do que antes fora.

Este excerto do livro revela um aspecto peculiar dos cartões-postais: a nostalgia que o leitor sente ao vê-los. Consideramos que esse sentimento pode ocorrer com intensidades diferentes, dependendo da relação que cada pessoa estabelece com a cidade que analisa. Se o morador acompanhou o processo de modernização ele verá as imagens de um modo, com uma empatia própria. Mas, se for um visitante que não conhece o local, pode, dependendo da análise que é capaz de empreender, observá-lo de modos distintos: ignorar o passado da cidade, vangloriando as conquistas da metrópole, ou olhar imagens antigas, comparando-as com a cidade atual, sentindo o pesar que acirrava o visitante de Maurília, descrito por Calvino. O ponto de mediação, seja qual for o sentimento suscitado, são os cartões-postais.

Diante desses apontamentos iniciais, poderíamos pensar: o processo de modernização de uma cidade pode ser conhecido por meio de cartões-postais?

uma nova forma de pensamento e de visão de mundo inaugurada pelo Renascimento e que se contrapõe à escolástica e ao estilo medieval. Segundo Harvey (2014), o projeto da modernidade relacionava-se ao esforço intelectual de pensadores iluministas para desenvolver a ciência objetiva, a moralidade, as leis universais e a arte autônoma. A ideia era usar o acúmulo de conhecimentos gerado até a ocasião em busca da emancipação humana e a melhoria da vida diária. O desenvolvimento de formas racionais de organização social e de modos racionais de pensamento prometia o domínio da ciência sobre a natureza, a libertação das irracionalidades do mito, da religião, da superstição, a liberação do uso arbitrário do poder, bem como do lado sombrio da própria natureza humana. Contudo, tal otimismo caiu por terra quando no século XX foram criados, em nome de tal desenvolvimento, os campos de concentração, o militarismo, as duas guerras mundiais e os ataques nucleares a Hiroshima e a Nagasaki. Marx e Engels (1990) compreendem a modernidade como transformação, mudança, novidade, revolução, que faz desmoronar antigas tradições, relações sociais, hábitos e preceitos até então rígidos e fixos. A modernidade envolve uma ruptura com as condições históricas precedentes e pode ser interpretada como portadora de uma tensão que ao mesmo tempo expressa perspectivas de destruição e de criação. Segundo Harvey (2014), a destruição criativa é uma das características do projeto da modernidade, pode ser reconhecida nas artes visuais e também na arquitetura por meio da grande preocupação com a criação de novos códigos que rompem com antigas linguagens, valorizando a inovação e a efemeridade. Nesse contexto, compreendemos que modernismo é um movimento que defende a renovação do pensamento e a ruptura com a tradição artística clássica. Já modernização se apresenta como um projeto da modernidade feito a partir de uma ideologia desenvolvimentista, do progresso e da racionalidade. Ela envolve a afirmação dos valores da classe social hegemônica e favorece a ampliação do capitalismo por meio de um processo de expansão territorial. A sua expressão pode ser identificada nas ruas, nas formas urbanas, nos sistemas de transporte, nos contrastes das cidades, nos diferentes lugares, na velocidade, na circulação de mercadorias etc. 
Os cartões-postais foram criados na primeira metade do século XIX. De acordo com Fernandes Júnior (2002) o surgimento desse tipo de comunicação postal simplificada e direta foi favorecido por condições sociais, econômicas e tecnológicas. Para esse autor, o cartãopostal pode ser entendido como integrante do início do processo de globalização econômica que buscava a internacionalização de diferentes países através do crescimento do comércio e dos fluxos migratórios de pessoas.

A regulamentação internacional e padronização dos cartões-postais no formato $14 \times 9 \mathrm{~cm}$, deu-se com a criação da Union Postal Universal, a partir de 1878, na França. A princípio eles eram puramente textuais e visavam transmitir mensagens rápidas e de baixo custo. No final do século XIX, abriu-se a possibilidade de eles serem editorados comercialmente, surgindo os primeiros cartões-postais ilustrados com desenhos, a partir de técnicas de gravura e que, posteriormente, passaram a incorporar as técnicas de impressão da fotografia. Atualmente os cartões-postais podem ser considerados como um gênero discursivo $^{2}$ que reúne as linguagens verbal e visual (FRANCO, 2006). Contudo, nos limites deste artigo, privilegiaremos a linguagem visual dos cartões-postais, suas relações com o entendimento do processo de modernização das cidades e com o campo educativo.

Os estudos sobre a cidade por meio dos cartões-postais constituem-se como lócus de pesquisa de pequeno interesse entre pesquisadores da área da educação. Dissemos isso porque constatamos por meio de levantamento realizado no Banco de Teses e Dissertações da Coordenação de Aperfeiçoamento de Pessoal de Nível Superior (Capes) que poucas pesquisas abarcam essa temática. Dos 586 registros a partir do descritor "cartões-postais", encontramos doze trabalhos, realizados entre 2013 e 2016, dos quais somente um apresenta pesquisa

\footnotetext{
${ }^{2}$ A partir dos pressupostos bakhtinianos consideramos que gêneros discursivos são enunciados relativamente estáveis que se constituem como lugar de emergência dos sentidos históricos das comunicações existentes em determinados contextos e com determinadas significações, e mantém vivas significações já socialmente consolidadas. Desse modo, os gêneros discursivos incluem todo o tipo de diálogos cotidianos bem como enunciações da vida pública, institucional, artística, científica e filosófica. Bakhtin (2003) posiciona os gêneros como primários e secundários. Os gêneros primários se formaram nas condições da comunicação discursiva imediata, já os secundários surgem nas condições de um convívio cultural mais complexo e relativamente mais desenvolvido e organizado. Ambos os tipos se relacionam entre si, em uma troca infinita de sentidos que renovam continuamente os gêneros. Por meio dessa instabilidade os gêneros vão se atualizando instaurando novos tipos e formas de enunciados que tentam se adequar a diversidade e as diferentes esferas da atividade comunicacional em contextos culturais específicos. Consideramos que o gênero discursivo cartão-postal é composto pela linguagem verbal e visual, portanto, pode se considerado como um texto verbo-visual.
} 


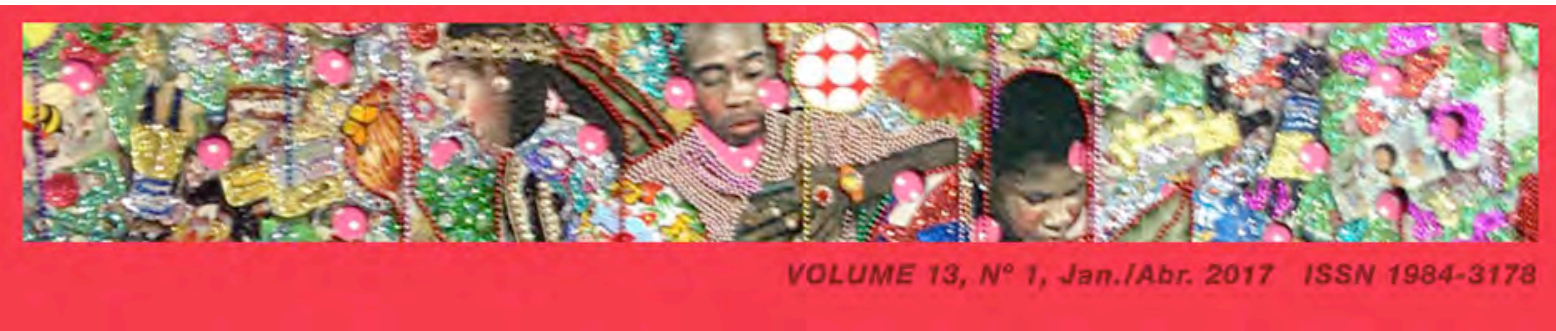

realizada em um programa de pós-graduação em educação. Trata-se da tese de Petry (2016), que tem como objeto de estudo a presença da Art Nouveau na arte gráfica brasileira, particularmente do Rio de Janeiro, entre os anos de 1895 e 1904. A autora analisou revistas e exposições de fotografias e também de cartões-postais que versavam sobre o tema abordado. Tal investigação aproxima-se da que estamos apresentando neste artigo, em especial, por utilizar o gênero textual "cartão-postal" como fonte de produção de dados para o estudo da cidade. Contudo, a autora não pontua a relevância dos cartões-postais como modo de mediar propostas educativas.

Diante da possibilidade de contribuir com esse nicho de pesquisa, elencamos como objetivo principal deste texto apresentar estudo sobre o processo de modernização da cidade de Vitória, no Espírito Santo, por meio dos cartões-postais, com vistas a analisar também o potencial histórico e educativo desse gênero textual. Para isso, além de realizarmos estudos sobre cartões-postais que retratam a cidade de Vitória, entre outros documentos e fontes bibliográficas sobre o assunto, exploramos dados produzidos pelo Grupo de Estudos e Pesquisas sobre Educação na Cidade e Humanidades (Gepech), do Instituto Federal do Espírito Santo (IFES). Em 2016 o grupo realizou 15 reuniões para discussão de textos teóricos sobre o tema educação na cidade, organizou 6 palestras com pesquisadores da área, 4 entrevistas em São Paulo com professores da Universidade Estadual de São Paulo (USP) e do Instituto Paulo Freire e também participou de três visitas a espaços expositivos da Grande Vitória, dentre eles o Espaço Cultural do Palácio Anchieta, para conhecer a mostra de cartõespostais, intitulada "Postais do Espírito Santo: acervo Monsenhor Jamil Abib". A exposição apresentou mais de 300 cartões-postais e ficou em cartaz de 19-01-2016 a 17-04-2016.

Como forma de sistematizar o artigo em tela, na primeira seção dialogaremos com autores que pesquisaram o processo de modernização da cidade de Vitória e também os que investigaram cartões-postais antigos dessa cidade. Para analisar esse processo, exibiremos cartões-postais que integram o acervo particular que pudemos conhecer em visita à referida mostra citada anteriormente. A seguir, apresentaremos a exposição de cartões-postais da coleção do Monsenhor Jamil Abib, revelando na terceira seção, depoimentos de integrantes do grupo de pesquisa Gepech, de modo a analisar por meio de tais dados empíricos, a contribuição da visita a referida exposição para o conhecimento do processo de modernização da cidade de Vitória. Para discorrer sobre esses depoimentos e imagens dos cartões-postais, 
interagiremos com apontamentos bakhtinianos referentes aos conceitos de dialogismo e polifonia, sem perder de vista as recomendações de Marco Polo ao apresentar a cidade de Maurília a Kublai Khan.

\section{A CIDADE DE VITÓRIA NO ESPÍRITO SANTO: PERCURSO DE SEU PROCESSO DE MODERNIZAÇÃO}

Apesar de historicamente o Espírito Santo estar localizado próximo aos principais polos econômicos do Brasil colonial, o Estado integrou a lógica de exploração mercantil das capitanias hereditárias de forma singular. No século XVIII o Espírito Santo era considerado uma das províncias mais pobres e até o final do século XIX possuía uma das menores populações do país. A descoberta do ouro em Minas Gerais não afetou o desenvolvimento do Espírito Santo, pois decidiu-se que o escoamento do ouro deveria ser realizado pelo porto do Rio de Janeiro, cabendo ao Espírito Santo apenas o papel de defesa natural para impedir o acesso à região de Minas Gerais. O governo reforçou os contingentes militares e impediu a abertura de qualquer estrada ligando o litoral capixaba a região do ouro. Conforme aponta Sueth (2004), o Espírito Santo devido a sua carência e pouca autonomia pode ser considerado um estado satélite, ou seja, "aquele que, por seu caráter secundário, não dispõe da autonomia necessária para reger seu destino e, por isso, depende de outra entidade que lhe proporcione os meios de sobreviver politicamente" (SUETH, 2004, p. 16-17).

O aumento da produção de café contribuiu para a mudança desse quadro de estagnação. Contudo, por não dispor de infraestrutura portuária para receber navios maiores, a produção cafeeira era levada para o Rio de Janeiro e comercializada por empresas exportadoras, mantendo a economia capixaba dependente do grande capital mercantil exportador, localizado na cidade do Rio de Janeiro. Principalmente por esses motivos, a cidade de Vitória, apesar de ser a capital do Espírito Santo, ficou isolada por muito tempo dentro do seu próprio território.

Atualmente Vitória possui 359.555 habitantes (CENSO IBGE, 2013), é composta por 34 ilhas, uma parte continental com área total de $96 \mathrm{~km}^{2}$ e possui $40 \%$ da área de seu território coberta por morros. Foi fundada em 1551 pelos colonos portugueses e, inicialmente, chamada Ilha de Santo Antônio. A antiga capital, Vila Velha, ficava em área próxima à baía, 


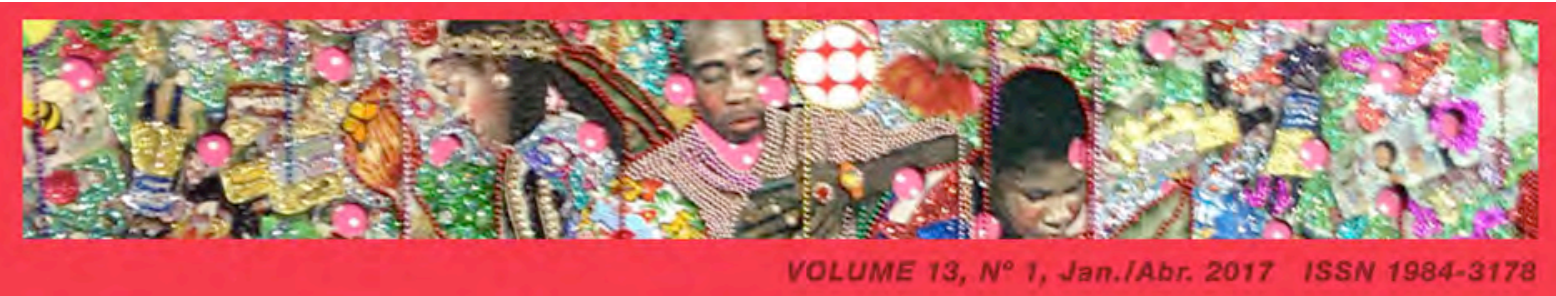

suscetível a ataques de embarcações piratas e a resistência a ocupação portuguesa por parte dos povos indígenas. Por isso, foi necessário mudar a capital do Estado para uma região que tivesse condições geofísicas que favorecessem a sua proteção/ocupação e que também contribuísse com a construção de fortificações como estratégia de defesa. Com essa mudança ocorreram os primeiros passos para realização de modificações na paisagem de Vitória.

Figura 1 - Cartão-postal da Escola de Aprendizes e Marinheiros do Espírito Santo

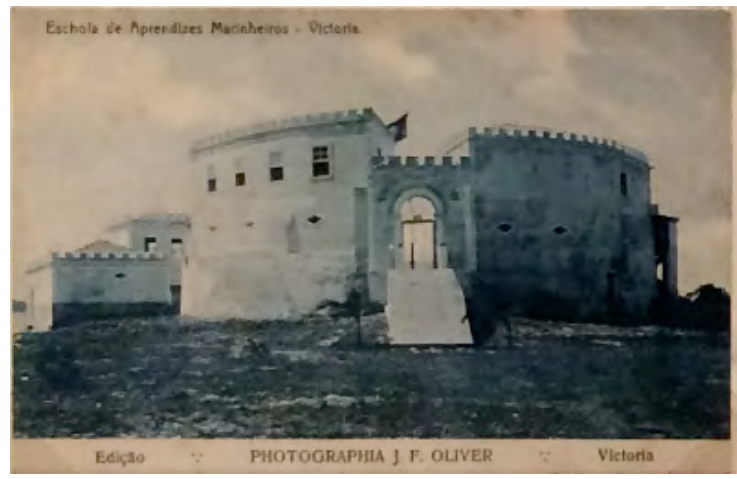

Fonte: Acervo Monsenhor Jamil Abib

Antes da mudança da capital para Vitória, algumas ações de defesa foram implementadas, entre elas a construção do Forte de São Francisco Xavier de Piratininga, localizado no município de Vila Velha. A sua construção foi iniciada em 1674, com o objetivo de incrementar a defesa da parte sul da baía de Vitória. O local escolhido para a edificação do forte foi o ponto em que aportou, em 1535, a caravela de Vasco Fernandes Coutinho, donatário da capitania do Espírito Santo. O formato circular da construção, apresentado na Figura 1, foi elaborado na reedificação iniciada em 1726. A partir de 1862, o Forte abrigou a Escola de Aprendizes e Marinheiros do Espírito Santo, apresentando a preocupação do governo com a formação de profissionais responsáveis pela segurança das águas capixabas. 
Figura 2 - Cartão-postal da Rua das Flores ou Rua Dionísio Rosendo

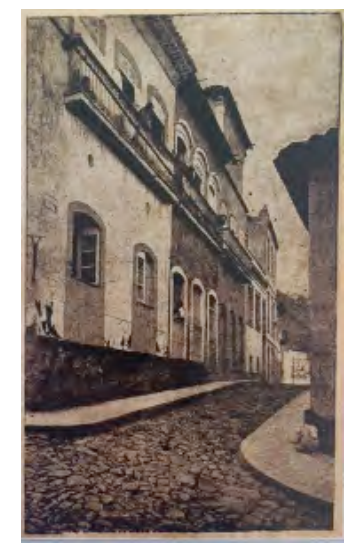

Fonte: LIMA JÚNIOR, 2012.

Conforme aponta Derenzi (1965), a Vila de Vitória era bem pequena e no início da colonização a população ocupava um pequeno território da ilha. Ela possuía ruas tortuosas e irregulares (Figura 2), com grandes aclives que dificultavam a circulação e a comunicação das pessoas, mas ajudavam a proteger a parte mais alta da cidade, onde se concentravam construções de destaque, como as igrejas por exemplo. De acordo com Lima (2013) essas construções eram compostas por fachadas com geometria básica, com frontão triangular, duas ou três janelas retangulares com função de iluminação e ventilação do coro localizado na parte mais alta do templo (Figura 3). Outro elemento arquitetônico importante era a torre sineira que conferia verticalidade à construção, evidenciando a superioridade divina.

Figura 3 - Cartão-postal da Igreja Matriz de São Thiago

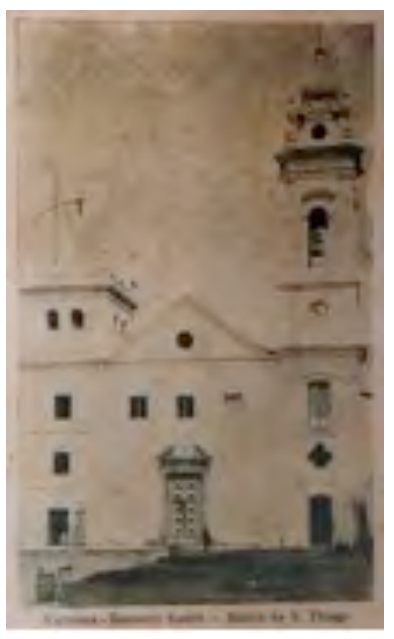

Fonte: LIMA JÚNIOR, 2012. 
Essas construções com posição de destaque demonstravam o poder e a força das instituições religiosas, constituindo-se como marcos visuais na paisagem (Figura 4), assim como marcos do poder simbólico ${ }^{3}$ (BOURDIEU, 1989).

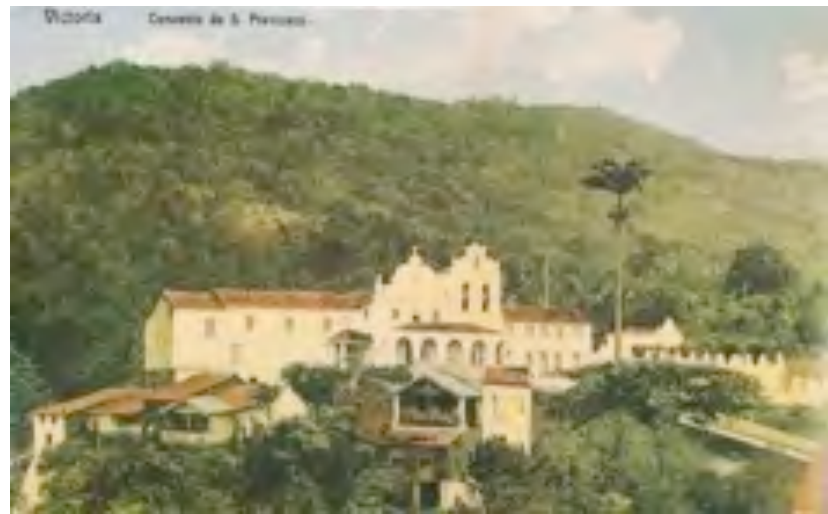

Fonte: LIMA JÚNIOR, 2012.

Até o início do século XIX, o desenho da cidade respeitou os limites da topografia do terreno, conforme os preceitos da arquitetura portuguesa, e seguiu suas barreiras naturais, tais como a baía de Vitória, o Maciço Central e as áreas alagadiças (Figura 5). Contudo, os governos que vieram a seguir acharam necessário expandir a área urbana da cidade, principalmente por meio de aterros, para impulsionar e atender ao crescimento econômico e demográfico que ocorria, imperativos comuns ao processo de modernização que se efetivava em várias cidades brasileiras e internacionais.

\footnotetext{
${ }^{3}$ Para Bourdieu (1989) o poder simbólico é um tipo de manifestação que somente pode ser mobilizado e efetivado com o envolvimento de entes sujeitados ou partícipes da produção desse poder, de modo relacional. Em cenas da vida quotidiana, é possível encontrar situações sociais tomadas como "naturais" e que se constituem pela manifestação do poder simbólico. Algumas relações estabelecidas por membros e por instituições religiosas podem servir como exemplo de poder simbólico apresentando-se por meio de relações interpessoais e interinstitucionais. É possível também afirmar que o poder simbólico está na vida cotidiana. Ele se instaura na vida cotidiana quando as pessoas são levadas a agir, a repetir gestos e atos numa rotina de procedimentos que não lhes pertencem, nem estão sob seus domínios, podendo ocorrer por meios místicos ou religiosos.
} 
Figura 5 - Cartão-postal com vista panorâmica da baía de Vitória

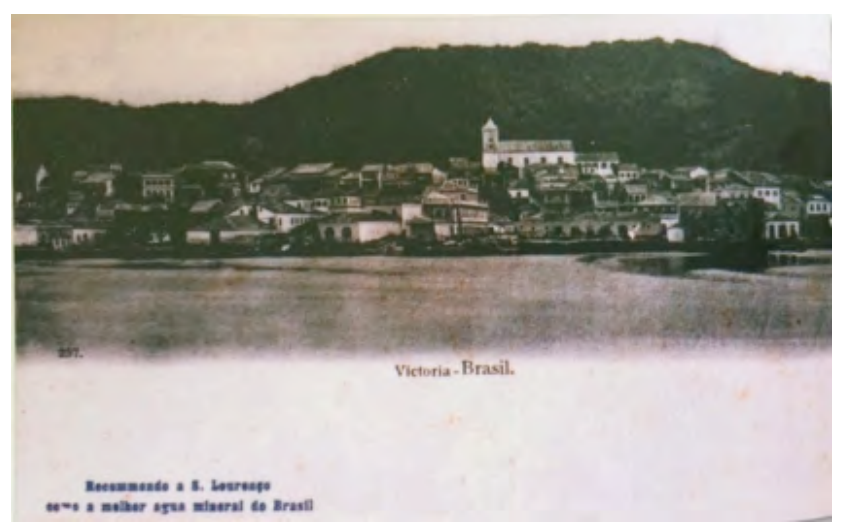

Fonte: LIMA JÚNIOR, 2012.

Entre 1812 e 1819 foram realizados vários aterros nas regiões alagadas próximas ao núcleo urbano central para a ocupação de novas áreas da cidade, fato que possibilitou a construção de novas ruas e residências. Esse tipo de intervenção provocou modificações no desenho e na percepção do sítio físico de Vitória. Um dos aterros realizados na ocasião foi o do manguezal do Campinho (Figura 6 e 7), com o intuito de fazer uma passagem para o centro da Vila e implementar ideias higienistas na região.

Figura 6 - Foto da região alagada do Campinho

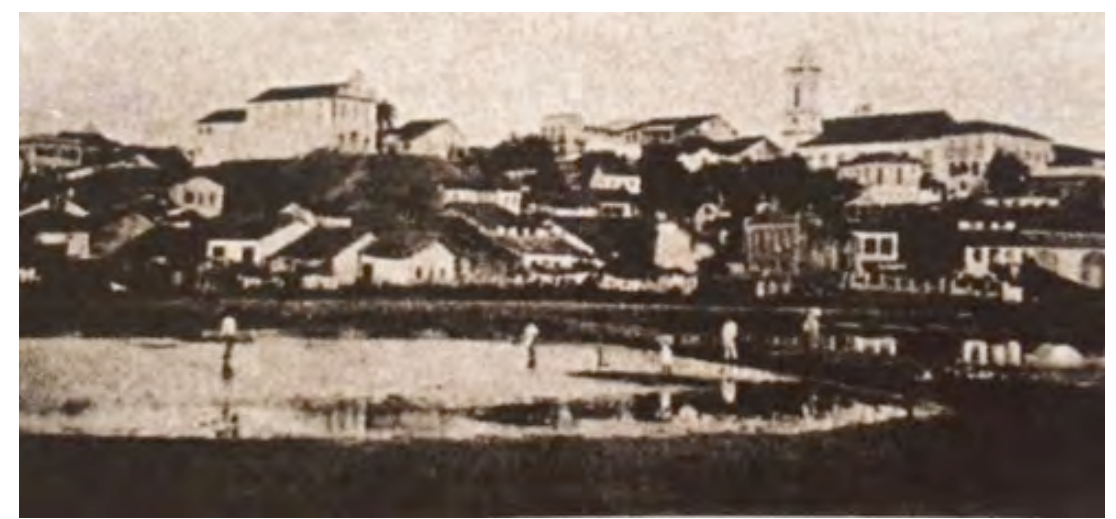

Fonte: Acervo do Arquivo Público do Estado do Espírito Santo.

De acordo com Derenzi (1965) as condições de higiene da cidade eram precárias. O lixo ocupava as ruas, quintais sujos, terrenos cobertos por mato, cemitérios na área urbana e 
muita pobreza. Os problemas referentes à insalubridade demoraram a serem resolvidos devido à falta de recursos financeiros. Além disso, os governantes limitavam-se a realizar obras de cunho mais popular que pudessem render-lhes popularidade.

Figura 7 - Cartão-Postal do Campinho aterrado

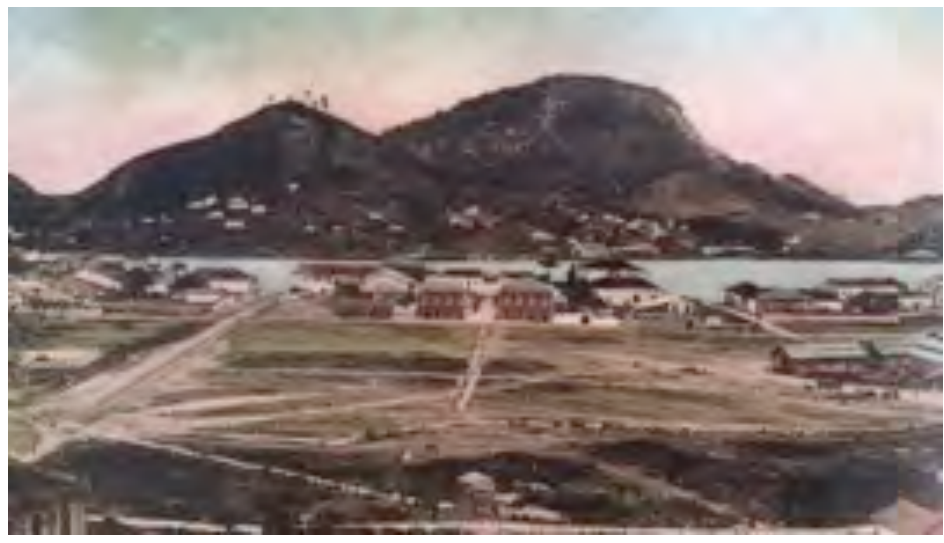

Fonte: Acervo do Arquivo Público do Estado do Espírito Santo.

Na figura 6 observamos uma área alagada, localizada na parte baixa da cidade. Já na figura 7, essa mesma região é mostrada totalmente aterrada, o que gerou a ampliação do espaço de ocupação da cidade de Vitória e deslocamento das pessoas que ali viviam. Nesse local foi construído o Parque Moscoso, primeiro parque urbano da capital, inaugurado em 1912.

Após drenagem e aterramento do local, foi construída uma grande praça (Figuras 8 e 9). A partir disso, o Parque Moscoso passou a ser ponto de encontro e de convivência dos capixabas abastados, fato que reforça a estratégia de classe, apontada por Lefebvre (1991), que visa retirar dos locais de convivência dos ricos, os pobres, encaminhando-os para os subúrbios e periferias da cidade. 


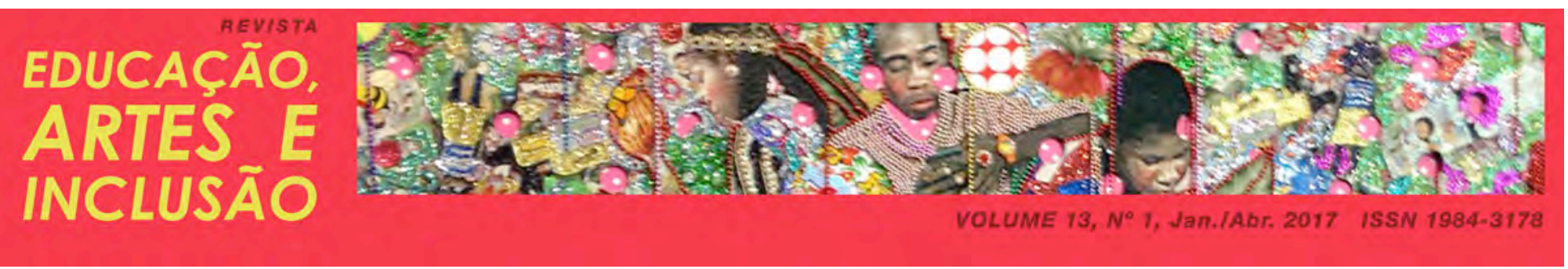

Figuras 8 e 9 - Cartões-Postais com vistas do Parque Moscoso
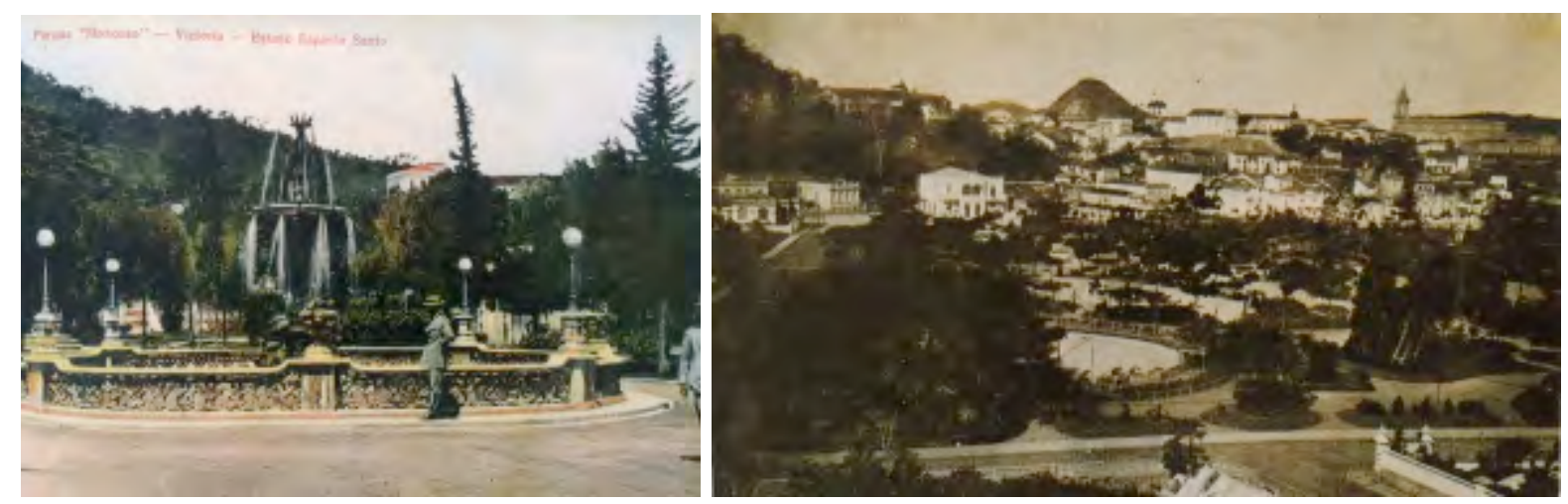

Fonte: LIMA JÚNIOR, 2012.

Ao final do primeiro momento do processo de modernização da cidade de Vitória, podemos destacar que durante o século XIX os aterramentos e as intervenções realizadas na paisagem de Vitória provocaram mudanças significativas no seu sítio físico, conforme mostra o mapa dos aterros realizados em 1830, representados pela cor laranja, e em 1860, representados pela cor rosa (Figura 10). Consideramos que os registros dessas mudanças, por meio da análise dos cartões-postais da época, são fundamentais para que compreendamos a trajetória histórica de urbanização desta cidade. Eles permitem que realizemos o acompanhamento das modificações que foram ocorrendo. São discursos visuais que nos ajudam a compreender aspectos históricos, sociais e culturais desta época. As comparações entre os locais são inevitáveis e nos fazem aludir ao texto de Calvino, quando diz que por meio dessas imagens podemos recordar com saudades aquilo que um dia a cidade foi. Além disso, é possível também compreender as estratégias usadas pelos governos da época para reafirmar seus projetos de modernização que englobavam um conjunto de transformações na estrutura econômica, política e cultural da cidade. 


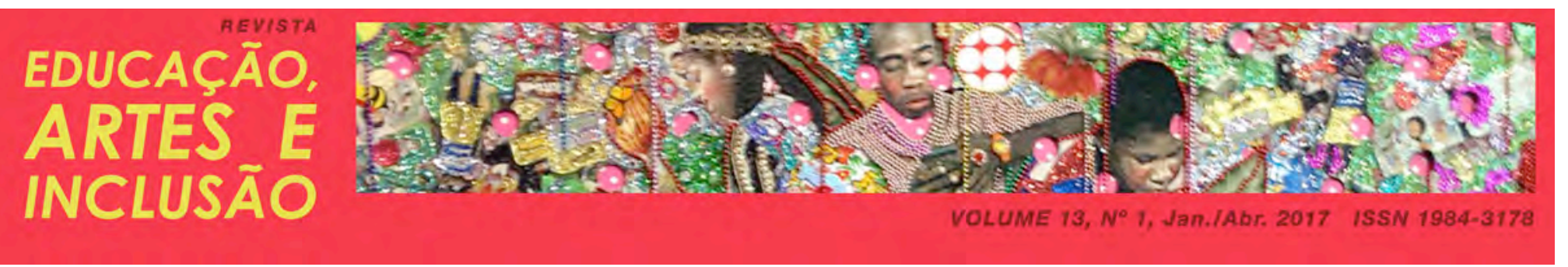

Figura 10 - Mapa dos aterros ocorridos no século XIX

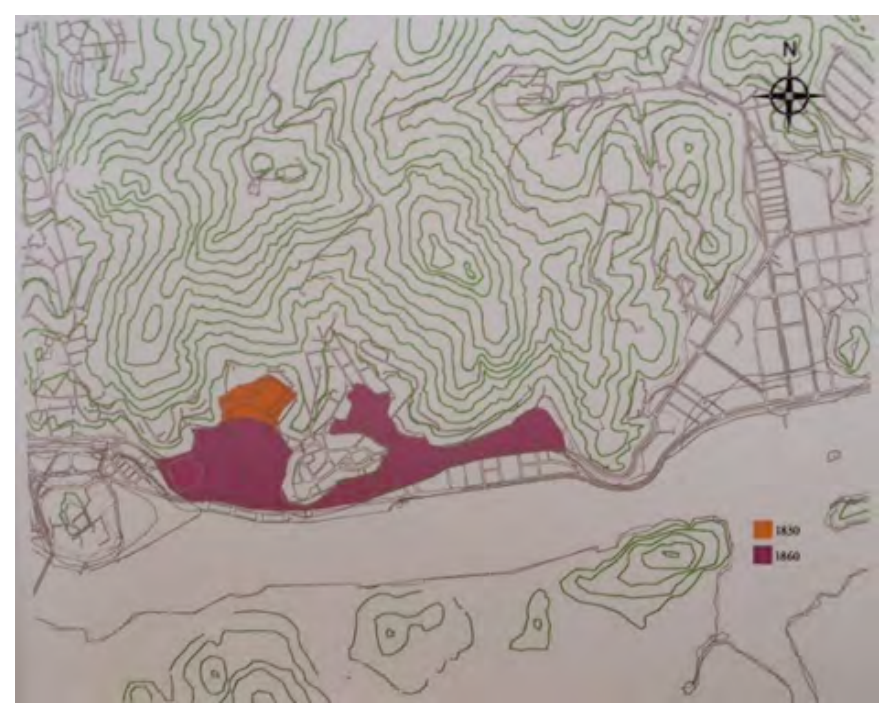

Fonte: KLUG, 2009.

De acordo com Klug (2009), o segundo momento do processo de modernização da cidade de Vitória ocorreu do final do século XIX até a década de 1950. Nessa ocasião a cidade passou por um grande processo de modernização, embelezamento e expansão promovido pelo poder público "que vai modelar partes da cidade e buscar novas áreas de expansão do tecido urbano" (KLUG, 2009, p. 25). O intuito era atender a burguesia enriquecida e adequar a cidade ao desenvolvimento imposto pela economia cafeeira, bem como fazer fluir de forma mais rápida o comércio da capital.

O núcleo central da capital colonial, cujo traçado seguia a topografia do terreno, com ruas estreitas, tortuosas e mal iluminadas, passa a ser alterado. As ruas são retificadas e as quadras ganham certa regularidade, buscando adequar o traçado colonial a um traçado moderno conforme novas referências criadas a partir do período republicano. Schutz-Foerste, Ferreira e Conti (2011) apontam que além de novas ruas e avenidas retilíneas foram construídas também calçadas largas, edifícios, praças e jardins públicos.

As fotografias dos cartões-postais da Praça do Palácio (Figuras 11 e 12) representam esses elementos modernizantes incorporados durante as reformas de diferentes espaços da cidade. Tais modificações ganharam relevo durante o projeto do "Novo Arrabalde" de 
Vitória, datado de 1896, que propõe a expansão da cidade por meio de reformas, construções e aterros, a partir da criação de novos bairros na cidade.

Figuras 11 e 12 - Cartões-postais da Praça do Palácio. Aspectos coloniais x modernos
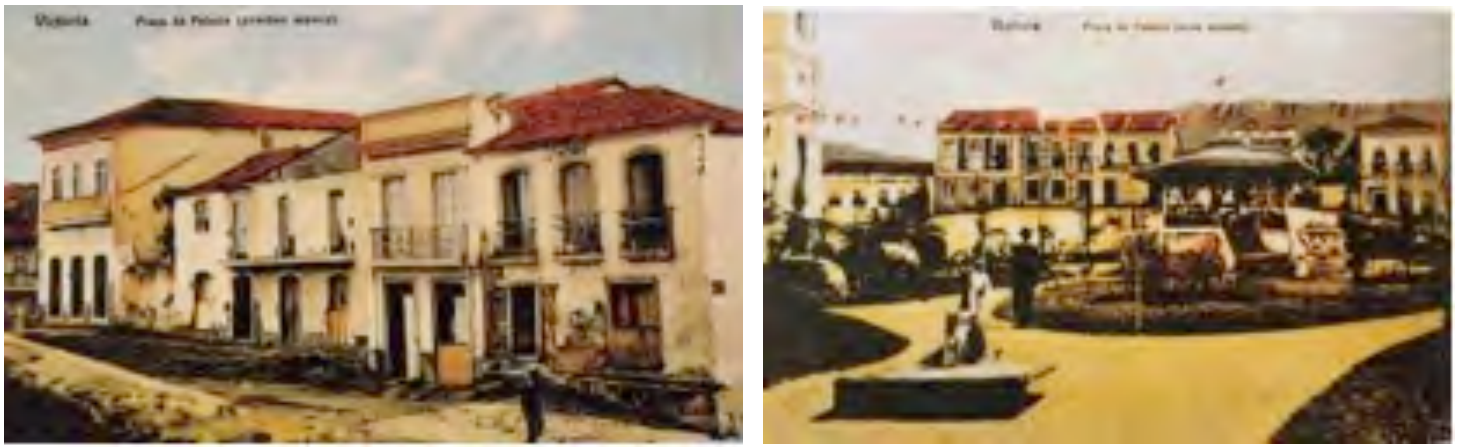

Fonte: LIMA JÚNIOR, 2012.

O desenho de Vitória proposto para o "Novo Arrabalde" consiste principalmente em duas avenidas longas e retas que acompanhavam o vale entre os morros presentes na região, convergindo para a saída Norte da cidade, como podemos verificar na área rosa à direita do mapa, próxima à baia do Espírito Santo (Figura 13). 


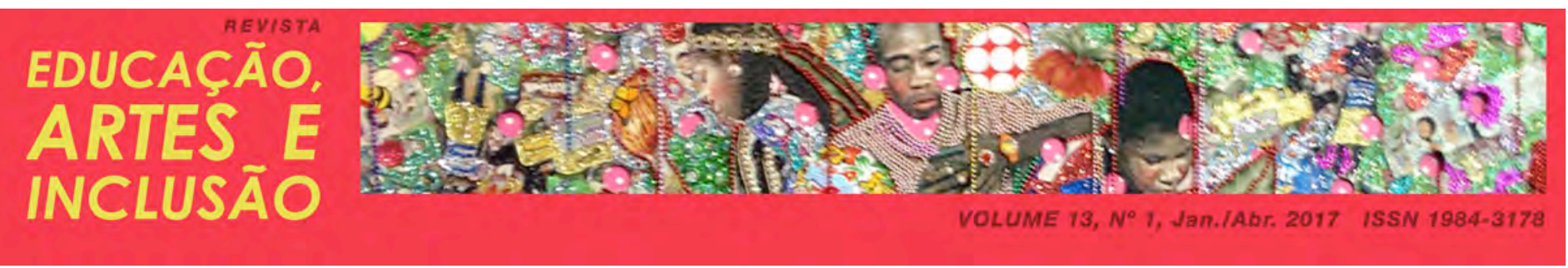

Figura 13 - Mapa do projeto do Novo Arrabalde, mostrando relação de escala entre o núcleo existente em 1896 e a área de expansão proposta

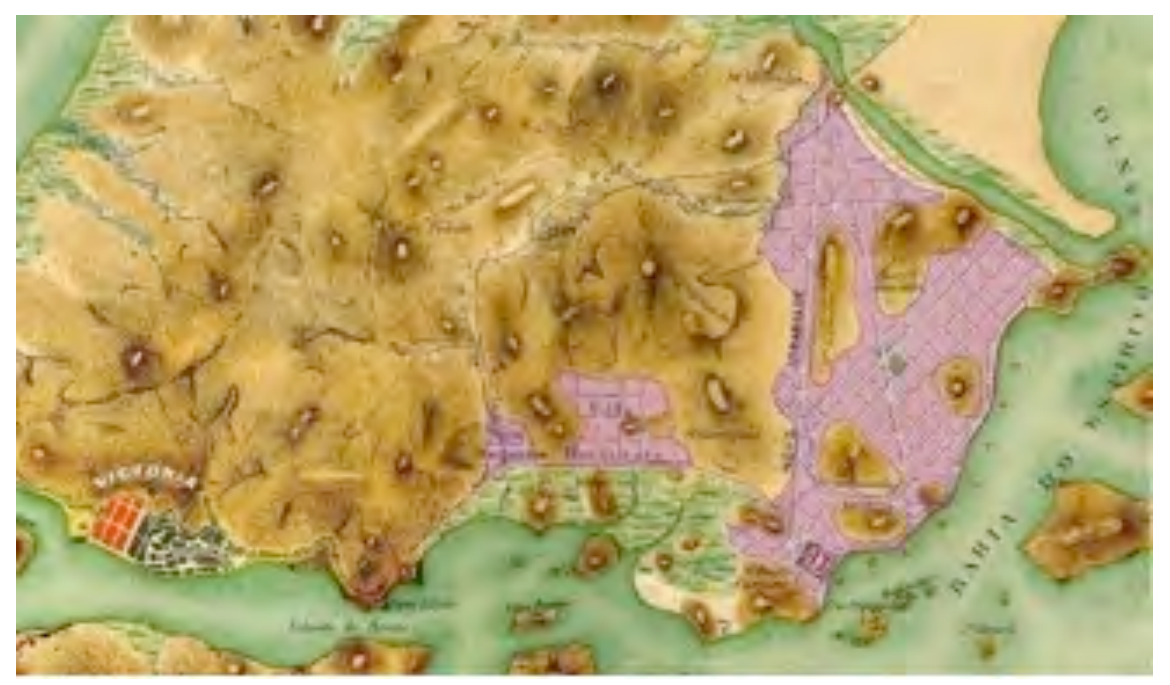

Fonte: Acervo Biblioteca Central da Universidade Federal do Espírito Santo.

Durante a primeira década do século XX, o movimento de modernização da cidade de Vitória cresceu e integrou o chamado "City Beautiful” que se destacava nos Estados Unidos e nas grandes intervenções urbanas ocorridas na Europa, em especial, a intervenção haussmaniana em Paris.

A partir de uma valorização estética da paisagem urbana com a construção de cenários, as cidades modernas se transformaram em símbolo do ideário republicano. Os planos de melhoramento e embelezamento das cidades tinham como principais preocupações a estética urbana, a construção de infra-estrutura nas cidades e reforma e ampliação dos portos. As ações prioritárias concentravam-se na realização de saneamento, abertura e regularização do sistema viário, com alargamento das ruas para facilitar a circulação de mercadorias e a comunicação do porto com o restante da cidade (KLUG, 2009, p. 30-31). 


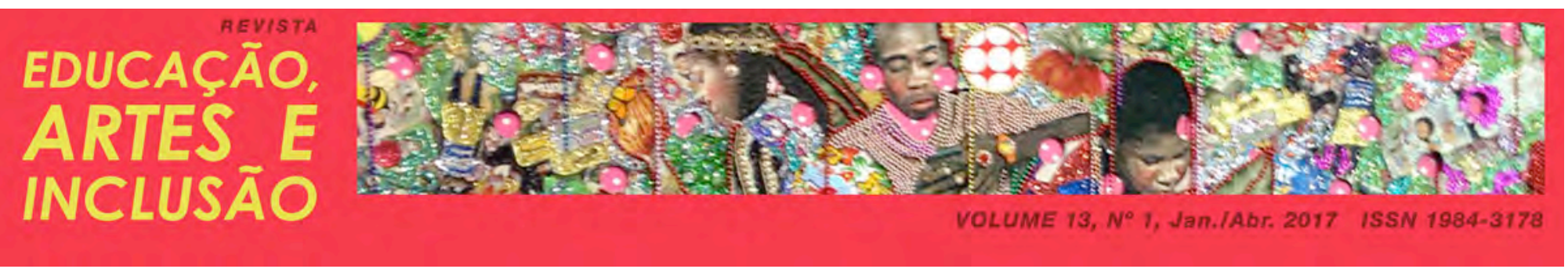

Figura 14 - Cartão-postal do Porto dos Padres em 1910

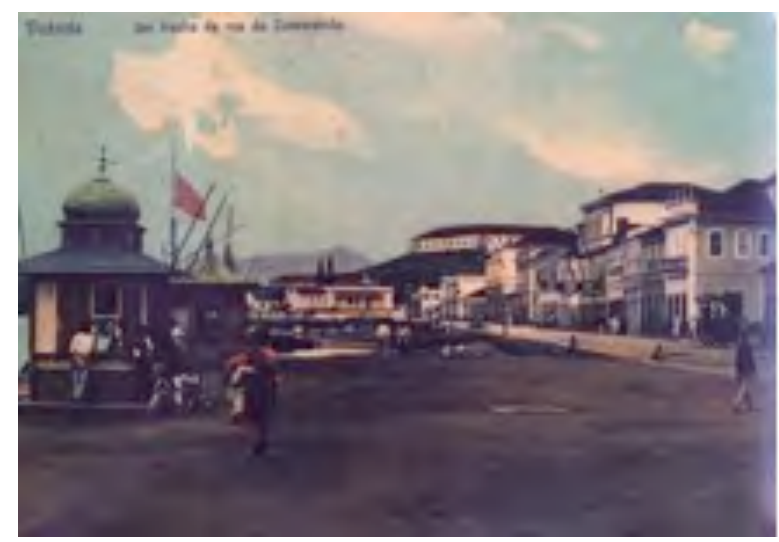

Fonte: Acervo Monsenhor Jamil Abib.

Conforme apresentado na figura 14 a área portuária de Vitória sofre alterações por meio de aterros para ampliar o cais e a Rua do Comércio e também pela construção de quiosques que visavam à comercialização de alimentos.

Durante a década de 1920, o plano de urbanização da cidade de Vitória foi ampliado e Vitória passou a contar com uma avenida reta e ampla, rompendo com a tipologia colonial de ruas estreitas e curtas (Figura 15). Nas décadas seguintes, os aterros foram aumentados, ampliando a extensão do Porto de Vitória (Figura 16). Conforme Santos (2015) a ampliação do porto contribuiu para o desenvolvimento econômico e político do Espírito Santo e buscou romper com a falta de estrutura que comprometia o fluxo econômico do estado.

Figuras 15 e 16 - Cartões-postais com tomadas aéreas da Avenida Jerônimo Monteiro e os aterros realizados na região do Porto de Vitória
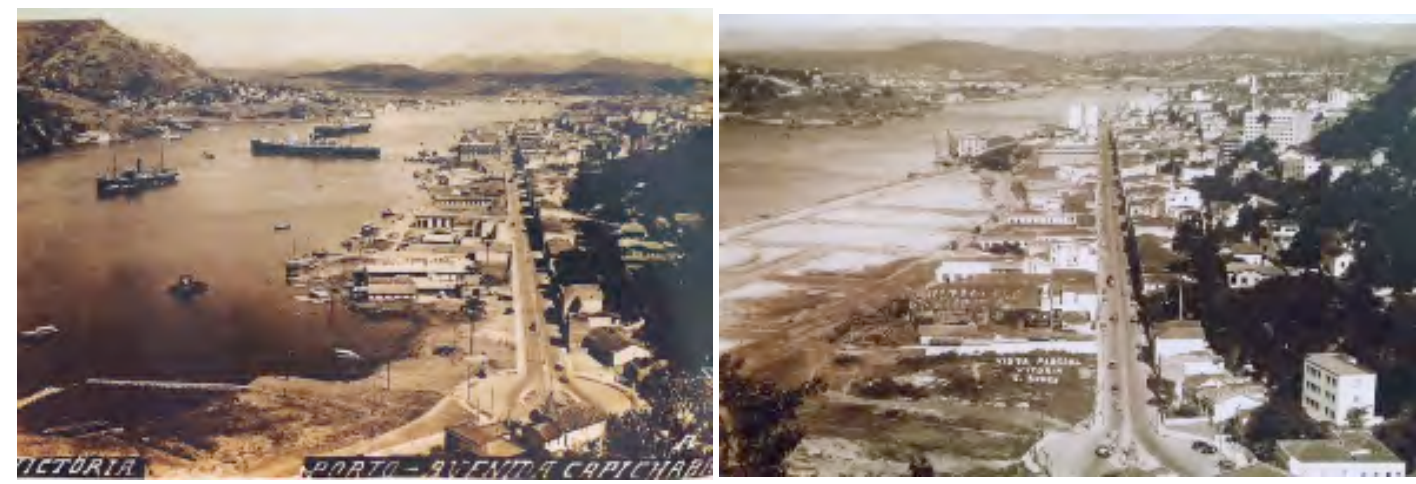
Ao mesmo tempo em que os planos de urbanização foram desenvolvidos, novos projetos começaram a ser aprovados, iniciando o processo de verticalização da cidade de Vitória (Figura 17). A construção de edifícios altos, com cerca de vinte andares, causou uma "severa ruptura visual na paisagem da cidade através da altura, da massa, da escala e da forma das edificações no contexto da paisagem natural" (KLUG, 2009, p. 45), tendo em vista que o maior prédio construído naquele momento possuía cerca de quatro andares. Novos aterros foram realizados, acabando quase por completo com os resquícios que existiam no centro da cidade de Vitória do antigo desenho da ilha.

\section{Figura 17 - Cartão-postal que apresenta os novos prédios da cidade de Vitória}

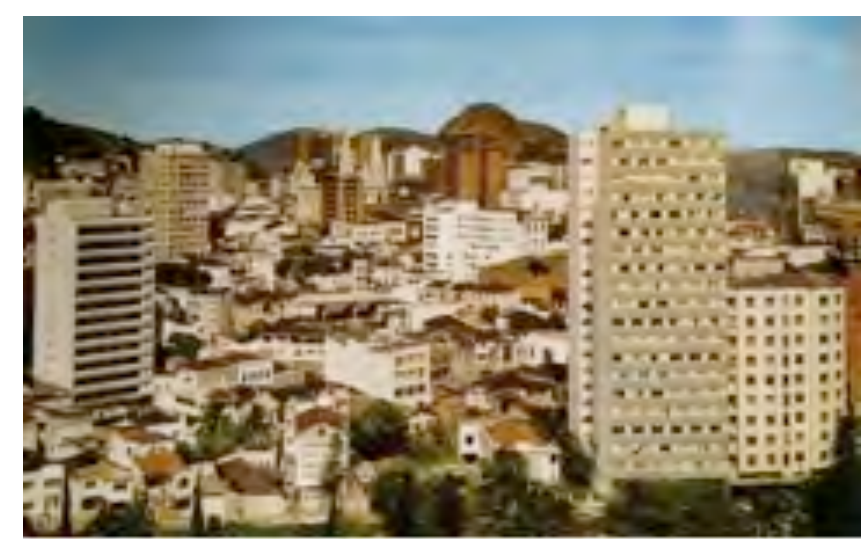

Fonte: LIMA JÚNIOR, 2012.

Conforme o mapa da figura 18 é possível inferir que o desenho da cidade colonial foi gradativamente sendo modificado por meio dos aterros que visam expandir o território da cidade. Nesse sentido, vários projetos foram planejados sendo o maior deles o voltado para a implementação do Novo Arrabalde. Cabe colocar que tal projeto foi implementado pelo 
governo do estado que financiou os aterros e a infraestrutura necessária para que os primeiros terrenos do bairro fossem comercializados (CAMPOS JÚNIOR, 1996).

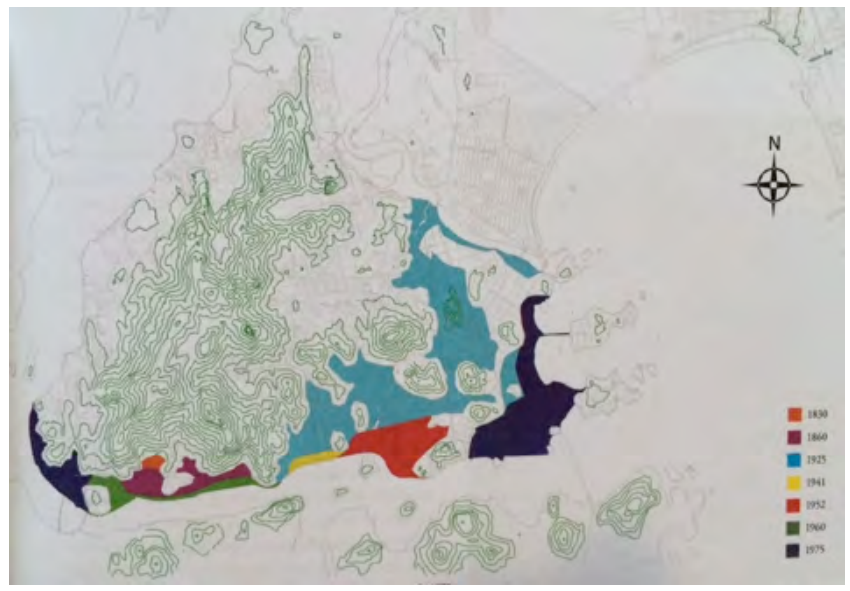

Fonte: Instituto Jones dos Santos Neves.

O terceiro momento do processo de modernização da cidade de Vitória iniciou-se a partir de 1950. Nessa ocasião a marcha da evolução urbana é intensificada pela verticalização e pela adoção de um modelo de planejamento pautado em leis e diretrizes. Esse processo vai modificando rapidamente a relação entre a paisagem natural e a paisagem construída de Vitória.

O processo de verticalização levou à formação de uma imensa barreira visual nas proximidades do mar com a cidade antiga, aparecendo apenas através de rasgos na massa edificada e entre galpões do porto. O centro antigo da capital ficou perdido e escondido entre um emaranhado de edifícios altos que sobrecarregaram visualmente um ambiente preparado para receber pequenas construções. Os novos elementos construídos passaram a figurar mais fortes na imagem do Centro de Vitória (KLUG, 2009, p. 51).

Entre 1951 a 1954 foram executados vários aterros destinados exclusivamente à implantação de edifícios. O aterro da Esplanada Capixaba (Figura 19) partiu do Centro de Vitória e seguiu até o bairro Bento Ferreira (Figura 20). Lima Júnior (2012) esclarece que as intervenções urbanas públicas ocorridas referentes principalmente às construções de edifícios 


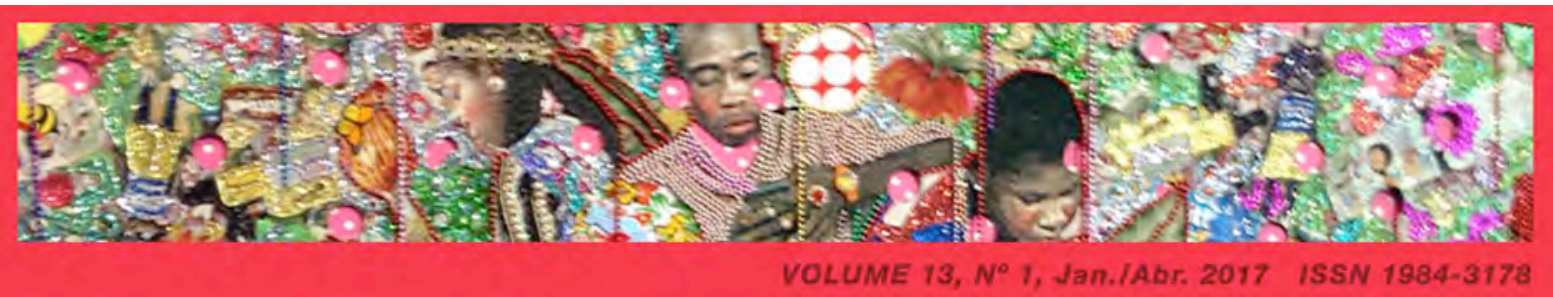

apresentaram-se não apenas como uma consequência da valorização do solo, propiciada pelas melhorias realizadas, mas como outra forma de expressão urbanística da modernização da cidade de Vitória.

Figura 19 e 20 - Cartões-postais da Esplanada Capixaba (1960) e do Bairro Bento Ferreira [1960?]
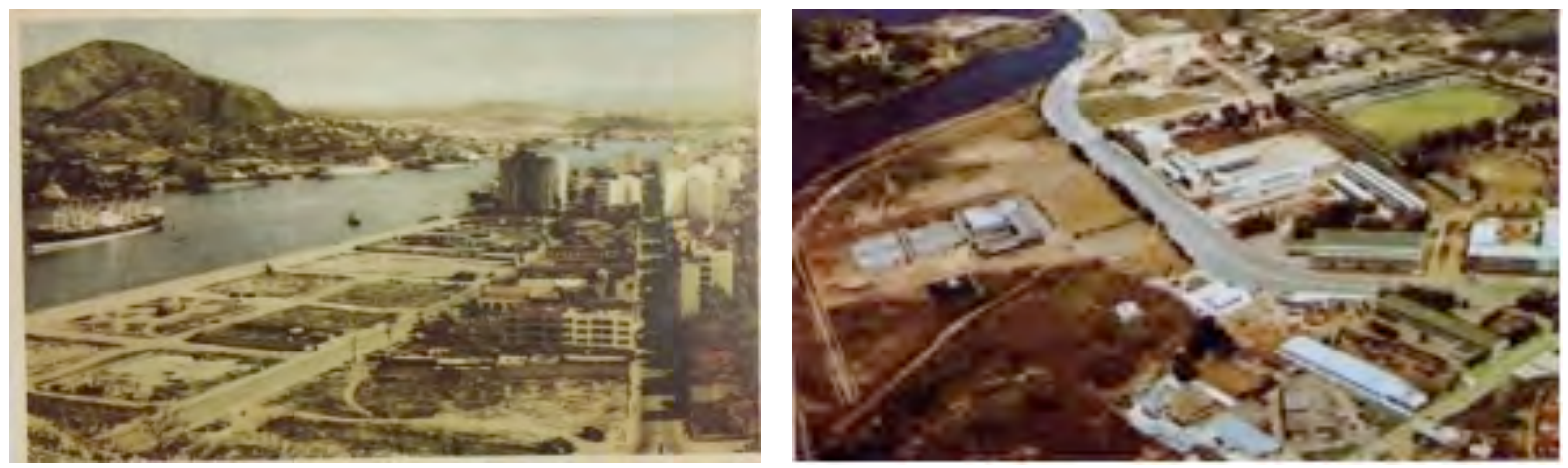

Fonte: LIMA JÚNIOR, 2012.

Por meio dessa rápida apresentação dos três momentos do processo de modernização da cidade de Vitória, é possível inferir que tais transformações modificaram a estrutura do sítio físico original, elemento estruturador da paisagem, da imagem e da identidade de Vitória. Desse modo, algumas referências naturais foram perdidas e novas referências foram criadas. Parafraseando o que escreveu Ítalo Calvino sobre Maurília, apesar do nome permanecer o mesmo, não é mais possível reconhecer a Vitória dos cartões-postais ao olhá-la na atualidade. A cidade com características coloniais foi banida. No lugar dos casarios, jardins, coretos e praças, suspenderam-se prédios que bloquearam a visão do traçado da cidade. Hoje quase não existe mais relação entre os postais e o que a cidade se transformou. "[...] os velhos postais não representam Maurília do passado, mas uma outra cidade que por acaso se chamava Maurília" (CALVINO, 1990, p. 31).

Desse modo, é assertivo considerar que os cartões-postais que apresentam a cidade de Vitória conseguem mediar de modo especial essas discussões, quando analisados em um conjunto de textos que se complementam e que registram uma história visual de 
transformação da cidade. A partir dessa constatação, na seção seguinte, buscaremos discorrer de modo mais ampliado sobre tais potencialidades pedagógicas.

\section{CARTÕES-POSTAIS DE VITÓRIA E SUAS POTENCIALIDADES EDUCATIVAS}

Privilegiar a utilização de cartões-postais como recurso para mediar processos educativos, em especial, os que abordam conhecimentos sobre o processo de modernização da cidade de Vitória, exige situar aspectos desse gênero discursivo e destacar contribuições de conceitos como dialogismo e polifonia, desenvolvidos por Bakhtin (2003).

Segundo Franco (2006), os postais podem ser concebidos como textos que apresentam fragmentos da história da cidade, pois retratam com predominância o ambiente urbano e suas conquistas tecnológicas. Sugere também que a compreensão desses textos não deve ser realizada no isolamento e limite dos seus elementos constituintes, mas precisa dialogar com outros textos que atravessam os cartões-postais como documentos escritos, fotografias registradas em épocas anteriores e posteriores, obras de artes e outros. Frehse (2005) em pesquisa sobre transformações do espaço urbano da cidade de São Paulo evidencia essas possibilidades de diálogo e desenvolve análises que coloca em articulação dados da vida comum, por meio de documentos como matérias jornalísticas sobre fatos cotidianos, atas da câmara e também cartões-postais que retratam diferentes tempos e espaços da cidade de São Paulo.

As proposições de Franco (2006) e Frehse (2000, 2005) sinalizam potencialidades educativas dos cartões-postais para o estudo da cidade, especialmente pela análise das imagens de paisagens, monumentos, lugares e pessoas que compõem esse gênero textual. Por meio dos textos visuais, os cartões-postais apresentam informações que superam suas finalidades comunicativas imediatas, ou seja, ultrapassam a ideia restrita de simples recurso utilizado para troca de mensagens rápidas e de baixo custo entre pessoas distantes. A produção de cartões-postais ilustrados materializa evidências sobre o desenvolvimento da arte da fotografia, das transformações de paisagens consideradas importantes em determinadas épocas, assim como as transformações técnicas e atividades gráficas vinculadas a essa linguagem. 


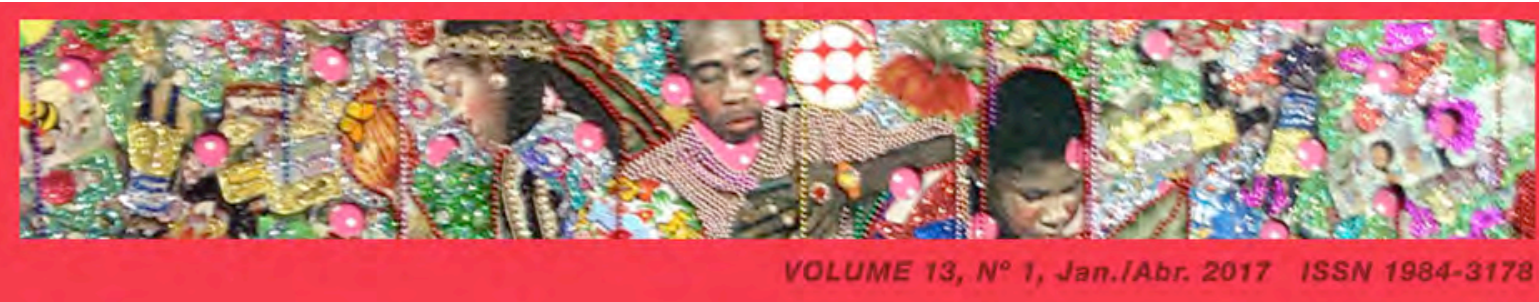

Sobre as técnicas de impressão, a história dos cartões-postais mostra que foi graças à colotipia (também conhecida como fototipia) que esse tipo de gênero discursivo se popularizou. Essa técnica permitiu o aumento das tiragens e a melhoria da nitidez da imagem da fotografia. A colotipia é um processo fotomecânico que

[...] se desenvolve a partir da criação de uma matriz de vidro com gelatina aderida e sensibilizada com bicromato de potássio. Sobre ela é colocado um negativo fotográfico e, depois de exposto à luz, a imagem se transpõe a matriz. Posteriormente, é lavada para a revelação e retirado o excesso químico. Por último, depois de seca, entinta-se a matriz, transferindo por contato a imagem para o papel. Trata-se ao final de uma imagem pigmentária que não tem, em sua composição, sais de prata nem processo químico como revelação e fixação (ESPÍRITO SANTO, 2016, p. 12).

A colotipia, como os demais métodos de impressão, contribuiu para a distribuição e o consumo massivo dos cartões-postais em nível mundial. Em 1906 foi criada pelos correios uma normativa que admitia maior espaço para as imagens, sendo permitido que uma face do cartão fosse utilizada para apresentar a imagem e a outra destinada a mensagens escritas e informações de endereço. Desse modo, cada vez mais as imagens ganharam destaque e espaço nos cartões-postais, passando a ser um elemento de forte caracterização e identidade desse gênero discursivo.

Além desse aspecto, é importante considerar que a ampliação da produção desse tipo de cartões-postais colaborou para a constituição de acervo de imagens de diferentes aspectos físicos, culturais, sociais e econômicos da sociedade, cujo conjunto de exemplares constitui fontes de preservação da memória das cidades, lugares, fatos e costumes tematizados. Assim, a partir de postais ilustrados, temos condições, mesmo que parciais, de conhecer transformações que ocorreram nas cidades, especialmente no período áureo de sua circulação no Brasil, que foi entre 1893 a 1930.

Segundo Franco (2006), a temática das imagens dos cartões-postais sinaliza-essas transformações. Para a autora, através desse gênero discursivo é possível entender as transformações das cidades e também diferentes contextos que revelam o antigo e o moderno. Ela considera que a modernidade é retratada nos cartões-postais a partir de ícones que evidenciam intervenções no espaço que consolidam a ideia do urbano. Essa tendência 
privilegia vistas de praças, prédios, circulação de pessoas, transporte, indústria, dentre outros aspectos. Esses temas postais revelam diálogos com o ambiente político, econômico e social de cada época e nos fazem perceber que os processos de modernização sofridos pelas cidades e analisados de modo comparativo por meio dos cartões-postais envolvem um conjunto de valores que, advindos de uma determinada classe social, se apresenta com forte caráter ideológico.

Alguns colecionadores conseguiram reunir material que apresenta essa tendência, tais como o acervo organizado por Monsenhor Jamil Abib, religioso paulista com formação em História e colecionador de cartões-postais, em especial exemplares sobre o Espírito Santo. Sua coleção reúne postais produzidos desde 1899, com grande valor histórico. Esse acervo foi objeto de exposição pública no Espaço Cultural do Palácio Anchieta denominada de "Postais do Espírito Santo - acervo Monsenhor Jamil Abib”, no ano de 2016 (Figura 21). É importante destacar que esses postais apresentam fatos comunicativos que retratam intervenções realizadas nos três grandes períodos que caracterizaram o processo de modernização da cidade de Vitória.

Figura 21 - Exposição Postais do Espírito Santo - acervo Monsenhor Jamil Abib

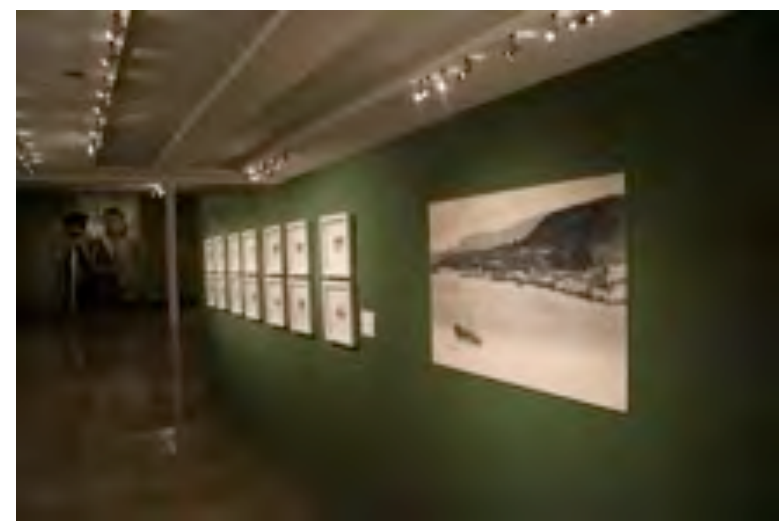

Fonte: Acervo dos autores, 2016

Diante do que foi apresentado, entendemos que os cartões-postais podem favorecer a ampliação e o aprofundamento do conhecimento da cidade. Uma das possibilidades de trabalho com cartões-postais é a análise comparativa. Comparar imagens de diferentes épocas 
pode estimular um olhar mais ampliado sobre os espaços da cidade, percebendo diferenças entre tempos históricos e a arquitetura de cada época, como sinalizamos no item um desse artigo. Esse tipo de comparação coloca a necessidade de estabelecer nexos entre textos produzidos em épocas distintas e por fotógrafos diferentes que provavelmente tinham intencionalidades diversas. Desse modo, é necessário estabelecer diálogos com esses gêneros discursivos. Como Bakhtin (2003) afirma, um ato de compreensão exige que o sujeito que interage com textos, no caso específico de nossas discussões sobre cartões-postais, assuma posição ativa e responsiva. Posicionamento ativo porque para compreender a narrativa visual dos cartões-postais e seus outros elementos é preciso formular indagações, cujas respostas podem gerar outras questões e a busca por outros textos. Assumir um lugar ativo responsivo diante da análise de textos alimenta o fluxo da comunicação verbal com a produção de novos textos, fruto do processo de reelaboração contínua dos sujeitos. Esses postulados de Bakhtin (2003) realçam que um texto produzido e preservado nunca morre, porque carrega em si a possibilidade de atualização futura, ou seja, de entrar em diálogo com outras esferas da comunicação humana, independente do seu tempo.

A perspectiva dialógica de estudo da cidade por meio de cartões-postais se apresenta ainda como possibilidade a partir da exploração comparativa desses textos com as características do espaço físico, natural e cultural do presente, considerando um conjunto de marcas objetivas, reais, como prédios, ruas, praças, fluxo das pessoas e dos transportes, tipos de trabalho, dentre muitos outros elementos singulares e gerais que integram o urbano. Nessa vertente, Canevacci (2004), em consonância com proposições de Bakhtin, entende que a cidade pode ser compreendida como um grande texto polifônico, ou seja, um texto constituído por diferentes enunciados que entrecruzam vozes. Vozes materializadas especialmente no conteúdo das imagens dos cartões-postais que revelam tempo e espaço distinto da cidade atual, mas que se cruzam e possibilitam outras leituras.

Nesse sentido, para captar essas vozes e colocar em diálogo os vários enunciados impregnados na cidade que podem nos ajudar a compreender o processo de modernização de Vitória, as fontes dos cartões-postais podem se constituir recursos interessantes para mostrar o movimento de intervenção e transformação do urbano. Para exemplificar tal potencial educativo propomos a realização de visita à Cidade Alta, primeiro núcleo urbano de Vitória, com o objetivo de explorar características das ruas, viadutos, escadarias, prédios históricos, 
árvores centenárias, igrejas, esculturas, praças, casarios e muitos outros elementos. Essa parte da cidade guarda marcas históricas do período de colonização portuguesa, ou seja, marcas do velho período que precisaram ser modernizadas para atender concepções ideológicas de seus governantes. Assim como apontou Calvino (1990), ao comparar ícones da sociedade rural (galinhas pelas ruas, moças de sombrinha caminhando e o coreto como atração da praça) com marcos referentes ao urbano (ônibus, viadutos e fábricas) na cidade de Maurília, podemos constatar, por meio dos cartões-postais antigos, que a cidade de Vitória aos poucos foi perdendo suas características originais, sendo essas silenciadas para que surgisse uma concepção de cidade que dialogasse com as inovações requeridas pelo processo de modernização e que trariam para a cidade a pretensa esperança de uma vida melhor e o reconhecimento que o Estado do Espírito Santo ainda não tivera, pois permaneceu por séculos funcionando como barreira natural para proteger a exploração aurífera na região das Minas Gerais.

A interação com os espaços físicos e culturais da parte alta da cidade de Vitória, bem como a mediação de conhecimentos relativos ao processo de sua constituição pode estimular reflexões dos estudantes que possibilitem a comparação e a compreensão da parte plana da capital e suas formas de utilização e ocupação do espaço urbano. A comparação e a reflexão das características desses dois planos da cidade, explorados em roteiros educativos que revelam intervenções diferenciadas, podem ocorrer com a análise de cartões-postais e outras fontes textuais, como mapas conforme os apresentados anteriormente por meio das figuras 10 , 13 e 18. Assim, os cartões-postais podem ser contemplados no processo educativo como modo de contribuir com a compreensão da cidade e, dessa forma, oferecem conhecimentos que o espaço real não possibilita pela observação direta. Consideramos, portanto, que a análise da cidade a partir de seu núcleo inicial, apresentados por cartões-postais antigos, constitui uma das possibilidades para organizar o estudo do processo de modernização das cidades.

É importante realçar que outras partes da cidade de Vitória evidenciam características de momentos da intervenção urbana que contribuíram para a transformação da cidade, como podemos notar em imagens de cartões-postais produzidos com o objetivo de apresentar os projetos industriais instalados na cidade de Vitória. 


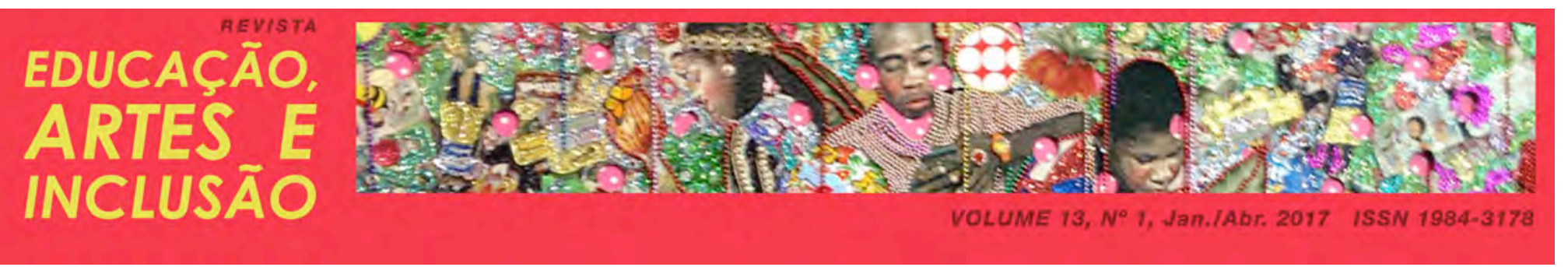

Figuras 22 e 23 - Cartões-postais sobre desembarque de minério no Porto de Vitória (1958) e sobre construção do Porto de Tubarão (1960)
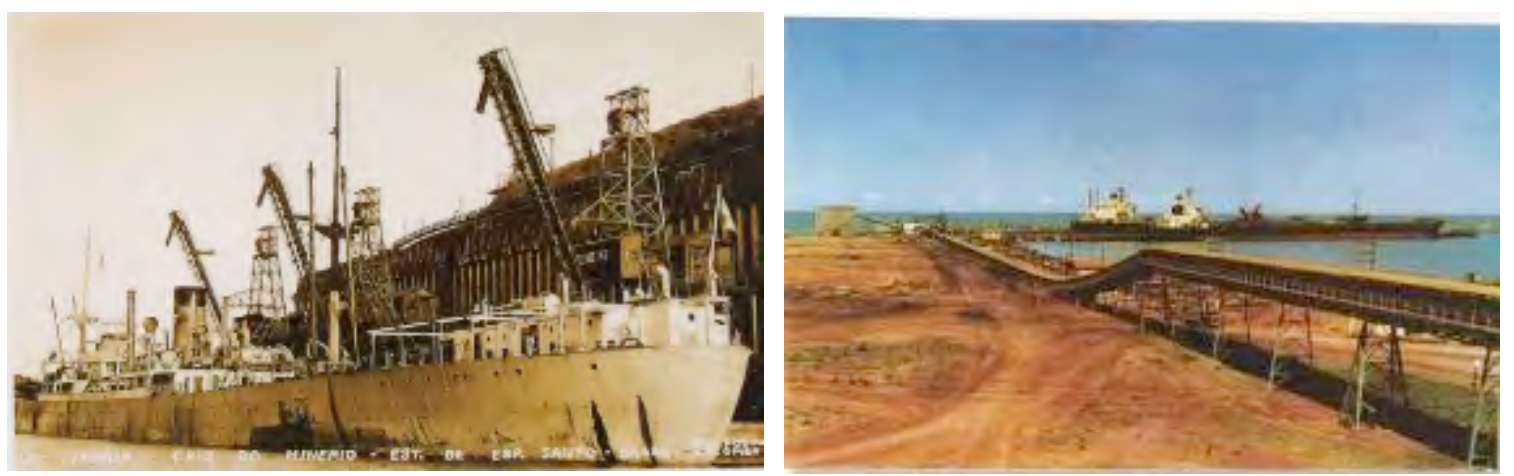

Fonte: LIMA JUNIOR, 2012.

Esses postais (Figuras 22 e 23) colocam em evidência as transformações que marcaram o terceiro período de modernização da cidade de Vitória, quando, a partir de 1950, projetos industriais ligados à mineração e à exportação foram implantados na cidade, sustentados pela ideologia desenvolvimentista. Segundo Santos (2015), nessa época o café era o principal produto a ser exportado, seguido pelo minério de ferro. Contudo, rapidamente o minério passa a ser "o principal item de exportação pelo Porto de Vitória, ao ponto de forçar sua ampliação para o continente - atualmente Terminal de Vila Velha - e posteriormente com a implementação do Porto de Tubarão" (SANTOS, 2015, p. 169).

$\mathrm{Na}$ esteira desses projetos, novos bairros populares e residenciais foram criados no entorno das empresas para abrigar trabalhadores envolvidos nesses projetos. Esse fato trouxe para a cidade consequências desastrosas, tais como o aumento da desigualdade social e os bolsões de pobreza instaurados na periferia e nos municípios limítrofes. Nesse sentido, a “explosão demográfica aliada ao modelo político que não permitia discussões em torno do formato de desenvolvimento e modernização implantado no estado, provocou grandes problemas, como a intensificação da favelização da população" (SANTOS, 2015, p. 170).

$\mathrm{Na}$ prática educativa as imagens dos cartões-postais (Figuras 22 e 23) podem ser problematizadas por indiciar discursos alusivos à política desenvolvimentista e mediar a explicitação de contradições geradas pelas construções destes portos. Além dos aspectos sociais elencados, outro ponto que pode ser realçado refere-se ao custo ambiental cobrado ao coletivo da cidade. A implantação desses projetos gerou intenso processo de poluição do ar e 
das águas da cidade de Vitória, ocasionando comprometimento da qualidade de vida das pessoas, bem como de seus bens naturais, como o ar e a praia. Harvey (2014) explica que a análise da cidade a partir desses aspectos contraditórios coloca em evidência o processo de privatização dos bens públicos como, por exemplo, a natureza. Para o autor, esse tipo de intervenção revela estratégias do capitalismo na direção de pensar a cidade sob a lógica da propriedade privada em detrimento do direito coletivo à cidade.

Diante dessas ponderações teóricas, defendemos que os cartões-postais são gêneros do discurso que podem contribuir com o estudo dos processos de modernização das cidades. Eles podem mediar práticas pedagógicas que irão colocar em diálogo espaços da cidade que não existem mais como outros que passaram a reconfigurar a cidade após seu processo de modernização. Dessa forma, compreendemos que a análise de elementos do passado mostrados nos cartões-postais e as reflexões sobre condições do presente possibilitam a tomada de consciência dos estudantes a respeito dessas contradições, cotejando formas de agir engajadas que poderão conduzir a outras formas de viver na cidade de Vitória.

Pensamos que esse tipo de trabalho pode ser viabilizado com o planejamento de roteiro educativo que realize visitas a variadas partes da cidade, de modo a confrontar esses espaços com cartões-postais antigos.

Que diferenças podemos observar nas representações da cidade (antiga e atual)? Conseguimos identificar referentes que expressam continuidades ou rupturas que caracterizam a cidade?

Explorar questões como essas e outras podem contribuir para o desenvolvimento de ações educativas que ampliem o conhecimento da cidade e de seu processo de modernização. Porém, entendemos que tais ações necessitam de materiais educativos específicos, planejados e organizados intencionalmente para essa finalidade, bem como espaços de formação continuada de professores que possam fomentar e instigar o interesse em abordar a cidade em diálogo com diferentes gêneros discursivos, dentre eles os cartões-postais. 


\title{
EDUCAÇÃO NA CIDADE E HUMANIDADES (GEPECH)
}

$\mathrm{Na}$ introdução deste texto indicamos algumas atividades relacionadas ao estudo da cidade de Vitória que foram realizadas pelo Gepech. Colocamos em destaque as visitas realizadas ao Centro Histórico de Vitória e, em especial, a exposição "Postais do Espírito Santo: acervo Monsenhor Jamil Abib”. O objetivo da visita foi conhecer os cartões-postais para ampliar o entendimento acerca do processo de modernização da cidade de Vitória e poder contribuir, após estudo ${ }^{4}$ aprofundado, para a elaboração de materiais educativos destinados a professores da educação básica.

Nessa exposição acessamos a outros tempos e espaços da cidade por meio dos cartõespostais, conhecemos e reconhecemos praças, ruas, prédios, fontes e monumentos. Essas observações nos remete a Freire (2007) quando aponta que a cidade revela estilos e gostos de certas épocas. Para esse autor,

\begin{abstract}
No fundo a tarefa educativa das cidades se realiza também através do tratamento de sua memória e sua memória não apenas guarda, mas reproduz, estende, comunica-se às gerações que chegam. Seus museus, seus centros de cultura, de arte são a alma viva do ímpeto criador, dos sinais de aventura do espírito. Falam de épocas diferentes, de apogeu, de decadência, de crises, da força condicionante das condições materiais (FREIRE, 2007, p. 26).
\end{abstract}

Compreendemos a partir desses pressupostos freireanos que visitas a diferentes espaços da cidade podem proporcionar reflexões e novos modos de pensar o espaço citadino. $\mathrm{Na}$ visita que estamos a relatar participaram dez mestrandos acompanhados pelas duas coordenadoras do Gepech. A duração da visita foi de aproximadamente duas horas e envolveu mestrandos de diferentes áreas de conhecimento na educação básica (Língua Portuguesa, História, Filosofia, Sociologia, Geografia, Pedagogia, Artes). Inicialmente a interação do grupo com o acervo da exposição foi conduzida pela mediação de um profissional da equipe técnica do Palácio Anchieta e depois seguiu de forma livre, onde cada participante pode se deter a fontes de seu interesse particular. Ao final da visita foi solicitado aos mestrandos que

\footnotetext{
${ }^{4}$ Em 2016 realizou uma série de ações com mestrandos do Programa de Pós-Graduação em Ensino de Humanidades do Instituto Federal do Espírito Santo, com o intuito de explorar o potencial formativo da cidade, a partir de visitas a espaços da cidade e estudos teóricos de autores internacionais como Lefebvre (1991, 1999), Harvey (2014), Canevacci (2004), assim como de obras nacionais de autoria de Chisté e Sgarbi (2015), Freire (2007), Gadotti e Padilha (2004), Silva (1979) e Klug (2009).
} 


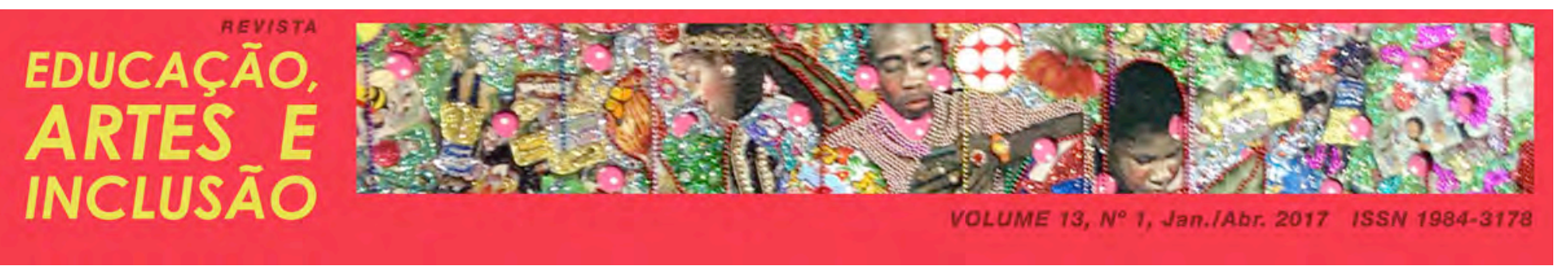

respondessem uma questão que buscava evidenciar o aprendizado sobre a cidade de Vitória que ocorreu por meio da visita à exposição de cartões-postais. Para exemplificar dados produzidos, apresentamos no Quadro 1, uma síntese de respostas ${ }^{5}$ obtidas.

Quadro 1 - Dados sobre visita à Exposição Postais do Espírito Santo - acervo Monsenhor Jamil Abib

\begin{tabular}{|c|c|}
\hline Participante & $\begin{array}{l}\text { Que conhecimentos presentes nos discursos visuais da exposição } \\
\text { visitada foram importantes para a reelaboração da compreensão da } \\
\text { cidade de Vitória? }\end{array}$ \\
\hline A1 & $\begin{array}{l}\text { Conhecer a Historia da cidade contribui para entender como ela se } \\
\text { desenvolveu e ajuda a pensar como ela ainda se desenvolverá. Para nós } \\
\text { educadores, esse é um aspecto muito importante, pois nos ajuda a planejar } \\
\text { ações a fim de formar cidadãos para habitarem a cidade. }\end{array}$ \\
\hline A2 & $\begin{array}{l}\text { Da exposição dos cartões-postais o que mais me marca são as } \\
\text { transformaçoses que a cidade passou. E a possibilidade de estar mais atento } \\
\text { aos detalhes dos monumentos da paisagem da cidade. }\end{array}$ \\
\hline P1 & $\begin{array}{l}\text { A exposição de Postais me despertou para a História do Espírito Santo e } \\
\text { suas especificidades. Além de resgatar a arquitetura belíssima. }\end{array}$ \\
\hline I1 & $\begin{array}{l}\text { A visita feita oportunizou conhecer melhor a história da cidade } \\
\text { e perceber as contradições contidas no espaço. }\end{array}$ \\
\hline D1 & $\begin{array}{l}\text { Visitar a exposição contribuiu para que eu remontasse a História da cidade } \\
\text { no tempo. A exposição de cartões-postais foi muito rica nesse sentido, pois } \\
\text { por meio das imagens, verifiquei como eram as ruas, os costumes, os } \\
\text { transportes, etc., o que me despertou um sentimento de valorização por } \\
\text { Vitória, uma compreensão maior da importância dos restauros dos prédios } \\
\text { do centro da cidade, trazendo aquela singeleza de tempos mais antigos, } \\
\text { onde os lugares de convivência eram mais valorizados. }\end{array}$ \\
\hline L1 & $\begin{array}{l}\text { As imagens revelaram uma outra cidade pouco conhecida e que tem grande } \\
\text { potencial educativo no entendimento da formação da própria cidade, dentre } \\
\text { outros temas. Mediante essa riqueza passei a perceber as potencialidades de } \\
\text { se trabalhar com leitura de imagem dentro do produto educacional. }\end{array}$ \\
\hline $\mathrm{I} 2$ & $\begin{array}{l}\text { É interessante perceber que cada pessoa tem uma forma de representar os } \\
\text { mesmos lugares. Isto é fascinante. As imagens, construções, enfim todas } \\
\text { estão lá, mas ela toca a cada um de uma forma diferente. Depende de cada } \\
\text { um. }\end{array}$ \\
\hline
\end{tabular}

Fonte: Elaboração do autor

\footnotetext{
${ }^{5}$ As respostas dos mestrandos foram identificadas pela letra inicial de seus nomes, seguida de numeral para distinguir os informantes.
} 
Os enunciados (Quadro 1) produzidos pelos participantes do grupo a partir da visita à exposição de cartões-postais do Espírito Santo sinalizam a potencialidade desse gênero discursivo para a revisão e/ou reelaboração de conhecimentos sobre a cidade. Inferimos que os diferentes extratos pontuam reflexões em várias direções, para além do conteúdo dos cartões-postais. Contudo, podemos perceber que a maioria das respostas enfatiza o potencial dos cartões-postais para a compreensão do processo de modernização da cidade de Vitória. Segundo os mestrandos, a visita à exposição proporcionou: conhecer a historia da cidade para entender como ela se desenvolveu e ajuda a pensar como ela ainda se desenvolverá (A1); observar as transformações que a cidade passou (A2); conhecer melhor a história da cidade e perceber as contradições contidas no espaço (I1), verificar como eram as ruas, os costumes e os transportes (D1) e revelar uma outra cidade pouco conhecida (L1).

Além de evidenciar o potencial dos cartões-postais para o estudo do processo de modernização da cidade as respostas discorreram também sobre outros temas. D1 ressaltou a importância de ações de restauro dos prédios históricos. Já P1 reconhece por meio dos cartões-postais a beleza da arquitetura da cidade. Os depoimentos apontam ainda que a interação com o acervo de cartões-postais pode favorecer subsídios para o planejamento de ensino, conforme realçado por A1.

Os discursos formulados pelos participantes do Gepech permitem reafirmarmos também o potencial educativo das visitas a espaços da cidade, entendendo-as como experiências coletivas de encontro com o conhecimento, com textos e com o outro, tendo como horizonte nosso processo de compreensão e humanização. Os cartões-postais ampliam nossa capacidade de ver, de ler e de compreender a cidade e suas transformações. Considerando esse potencial, alguns mestrandos optaram por utilizar esse gênero discursivo em suas propostas de pesquisas que discutem temas específicos da cidade. Os cartões-postais utilizados foram selecionados conforme foco de cada estudo. Essas pesquisas, embora em andamento, formularam propostas de materiais educativos que contemplam roteiros de visitas a espaços específicos da cidade, como parques, praças, prédios, igrejas, museus, bem como a espaços naturais como praias e orla da cidade de Vitória.

Esses roteiros de visitas a espaços da cidade que integram os materiais educativos 
formulados pelo Gepech serão estudados, discutidos e problematizados com professores da rede pública em ações de formação continuada. Esses encontros de formação continuada tem o intuito de dialogar com os professores da educação básica sobre possibilidades e limites das propostas que defendem o estudo da cidade de Vitória. Caber realçar que nesses materiais educativos os roteiros educativos são permeados por textos visuais e verbais, como a fotografia, os cartões-postais, a poesia, a literatura, as obras de artes, os textos jornalísticos dentre outros, evidenciando a dialogicidade e a polifonia (CANEVACCI, 2004) que integram o conhecimento da cidade. Especificamente, os cartões-postais trazem significativas contribuições por apresentarem imagens da cidade valorizadas socialmente em outras épocas. A abordagem comparativa dessas fontes com outras favorecem a compreensão de elementos do espaço físico, natural e social que compõem a tessitura urbana.

Compartilhar essas perspectivas de estudo da cidade por meio de ações de formação continuada consistem nos próximos horizontes de ações do Gepech que visam a articulação de atividades de ensino, pesquisa e extensão do Instituto Federal do Espírito Santo, no âmbito do Mestrado em Ensino de Humanidades. Essas ações estão organizadas a partir de momentos dialógicos (BAKHTIN, 2003) de estudos coletivos, sistematizados por adesão voluntária dos professores, e de visitas a espaços da cidade, por entendermos que todos, pesquisadores, professores e estudantes tem direito à cidade (LEFEBVRE, 2001), em sua dinâmica urbana que pode ser percebida como potencialmente educativa.

\section{CONSIDERAÇÕES FINAIS}

Finalizamos esse artigo com a compreensão de que cartões-postais guardam potencial para explorar diferentes aspectos sobre o processo de modernização da cidade de Vitória no Espírito Santo. Para tanto, apresentamos histórico e explicitamos os três momentos principais desse processo; situamos informações sobre a história de constituição do gênero discursivo cartão-postal, salientando que ele deve ser explorado em diálogo com outros textos, em uma perspectiva crítica. Nessa direção, buscamos apresentar possibilidades de ações educativas que contemplem os postais como fontes de memória da cidade, exemplificando como as narrativas visuais desse gênero discursivo podem ser colocadas em diálogo com elementos 
físicos, naturais e culturais da cidade.

Por meio de metodologia comparativa, mostramos que os cartões-postais podem favorecer a compreensão de conhecimentos sobre a cidade a partir da análise de diferentes cartões-postais. Evidenciamos ainda estratégias de utilização dos cartões-postais como gêneros discursivos que revelam informações sobre a cidade que não podem ser observados na materialidade dos espaços urbanos atuais. Esse modo de pensar a utilização de postais para o estudo do processo de transformação e modernização da cidade apresenta contribuições, conforme relatos de membros do grupo de pesquisa que realizaram visita à exposição pública sobre postais do Espírito Santo.

A partir do exposto, reforçamos a viabilidade da utilização dos cartões-postais como recursos para estudos da cidade, sendo importantes também para ações de formação continuada de professores que visam elaborar coletivamente material educativo que apresente estratégias dialógicas de estudo sobre a cidade. Portanto, consideramos que ações voltadas para a formação contínua de professores podem contribuir com a divulgação e conhecimento do potencial educativo dos cartões-postais, favorecendo o entendimento da cidade como espaço urbano marcado por contradições e estratégias de classe.

Para finalizar, consideramos, por meio do texto literário de Calvino, que em Vitória, assim como em Maurília, as marcas da colonialidade não foram vistas como graciosas. Será que tais marcas seriam observadas dessa maneira se estivessem presentes até os dias de hoje? Seríamos um outro exemplar famoso mundialmente pela preservação da arquitetura colonial? Ficam somente as elucubrações alusivas a Maurília calviniana e às memórias presentes nos cartões-postais para recordarmos com saudades aquilo que um dia a cidade foi.

\section{REFERÊNCIAS}

BAKHTIN, M. Estética da criação verbal. São Paulo: Martins Fontes, 2003.

BOURDIEU, P. O poder simbólico. Rio de Janeiro: Editora Bertrand do Brasil, 1989.

CALVINO, I. Cidades invisíveis. São Paulo: Companhia das Letras, 1990. 
CANEVACCI, M. A cidade polifônica: ensaio sobre a antropologia da comunicação urbana. São Paulo: Studio Nobel, 2004.

CAMPOS JÚNIOR, Carlos Teixeira de. O novo arrabalde. Vitória: PMV, Secretaria Municipal de Cultura e Turismo, 1996.

CHISTÉ, P. de S.; SGARBI, A. D. Cidade educativa: reflexões sobre educação, cidadania, escola e formação humana. Revista Debates em Educação Científica e Tecnológica, Vitória, v. 6, n. 1, out. 2015.

DERENZI, Serafim. Biografia de uma Ilha. 2a ed. Vitória, Secretaria Municipal de Cultura e Turismo, 1995.

ESPÍRITO SANTO. Material educativo da exposição Postais do Espírito Santo: acervo Monsenhor Jamil Abib. 2016.

FERNANDES JÚNIOR, R. Apresentação. Postaes do Brazil. São Paulo: Metalivros, 2002.

FRANCO, P. dos S. Cartões-postais: fragmentos de lugares, pessoas e percepções. Métis: história e cultura, 2006, p. 25-62.

FREHSE, F. O tempo das ruas na São Paulo de fins do Império. São Paulo: Editora da Universidade de São Paulo, 2005.

Cartões postais paulistanos na virada do século XX: problematizando a São Paulo "moderna". Horizontes Antropológicos, Porto Alegre, ano 6, n. 13, p. 127-153, jun. 2000.

FREIRE, P. Educação permanente e as cidades educativas. São Paulo: Vila das Letras, 2007.

GADOTTI, M.; PADILHA, P. R. Escola Cidadã, cidade educadora: projeto políticopedagógico e práticas em processo. In: GADOTTI, Moacir; PADILHA, Paulo Roberto; CABEZUDO, A. Cidade educadora: princípios e experiências. São Paulo: Cortêz, 2004.

HABERMANS, Jürgen. A constelação pós-nacional: ensaios políticos. Trad. Márcio Seligmann-Silva. São Paulo: Littera Mundi, 2001.

HARVEY, D. Cidades Rebeldes. São Paulo: Martins Fontes, 2014. . A condição pós-moderna. São Paulo: Edições Loyola, 2014.

JAPIASSU, Hilton; MARCONDES, Danilo. Dicionário básico de filosofia. Rio de Janeiro: Jorge Zahar, 2008.

KLUG, L. B. Vitória: sítio físico e paisagem. Vitória: EDUFES, 2009.

LEFEBVRE, H. O direito à cidade. São Paulo: Moraes, 1991.

A Revolução Urbana. Belo Horizonte: Editora UFMG, 1999. 
MARX, Karl; ENGELS, Friedrich. Manifesto do Partido Comunista. Rio de Janeiro: Vozes, 1990.

PETRY, Michele Bete. Revistas como exposições: Arte do Espetáculo e Arte Nova (Rio de Janeiro, 1895-1904). 2016. Doutorado em Educação: Universidade Federal de Santa Catarina, Florianópolis. $319 \mathrm{f}$.

SANTOS, Leonardo Bis dos. A modernidade chega de navio: ensaio sobre o desenvolvimento do Espírito Santo pelo viés da expansão portuária. In: RIBEIRO et all. Modernidade e modernização no Espírito Santo. Vitória/ES, Edufes, 2015. p. 157-178.

SILVA, J. I. da. Cidade Educativa: um modelo de renovação da educação. São Paulo: Cortêz \& Moraes, 1979.

SCHUTZ-FOERSTE, Gerda Margit; FERREIRA, Sônia Maria de Oliveira; CONTI, Raquel Félix (Org.). Relendo imagens, atribuindo significados: as cidades que devem ser esquecidas. Vitória: GM Gráfica e Editora, 2011.

SUETH, José Candido R. Espírito Santo, um Estado "satélite" na Primeira Republica: de Moniz Freire a Jerônimo Monteiro (1892/1912). 2004. 146f. Dissertação (Mestrado em História) - Programa de Pós-Graduação em História, Universidade Federal do Espírito Santo, Vitória, 2004.

Recebido em 14 de novembro de 2016 Aprovado em 31 de março de 2017 